\title{
Inotropic effects of prostacyclins on the right ventricle are abolished in isolated rat hearts with right ventricular hypertrophy and failure
}

Sarah Holmboe, $\mathrm{MD}^{1}$, Asger Andersen, MD, $\mathrm{PhD}^{1}$, Jacob Johnsen, $\mathrm{MD}^{1}$, Jan Møller Nielsen, MD, $\mathrm{PhD}^{1}$, Rikke Nørregaard, MSc, $\mathrm{PhD}^{2}$, Hans Erik Bøtker, MD, PhD, DMSc ${ }^{1}$, Lucie H. Clapp, BSc, $\mathrm{PhD}^{3}$, Jens Erik Nielsen-Kudsk, MD, PhD, DMSc ${ }^{1}$

\footnotetext{
${ }^{1}$ Aarhus University Hospital, Department of Cardiology and Aarhus University Institute of Clinical Medicine, Denmark.

${ }^{2}$ Aarhus University, Institute of Clinical Medicine, Denmark.

${ }^{3}$ University College London, Institute of Cardiovascular Science, United Kingdom.
}

\section{Correspondance:}

Sarah Holmboe, Department of Cardiology - Research, Aarhus University Hospital Palle Juul-Jensens Boulevard 99, 8200 Aarhus N, Denmark

Phone: +45 22966983, Email: shol@clin.au.dk, holmboe.sarah@gmail.com

\section{Funding}

Danish Heart Foundation [12-04-R90-A3793-22694]

Danish Children's Heart Foundation [14-R97-A5009-26020, 13-04-R93-A4567-26011]

AP Møller Foundation

Aarhus University

Snedkermester Sophus Jacobsen og hustru Astrid Jacobsens Fond 


\section{Conflict of interest}

United Therapeutics Corporation provided a grant for materials to another study, of which Sarah Holmboe is a co-author. Lucie H. Clapp has received educational grants from United Therapeutics Corporation not related to the present study. All other authors have nothing to declare.

Running title: Prostacyclins and right ventricular failure

Abstract

\section{Background:}

Prostacyclin mimetics are vasodilatory agents used in the treatment of pulmonary arterial hypertension. The direct effects of prostanoids on right ventricular (RV) function are unknown. We aimed to investigate the direct effects of prostacyclin mimetics on RV function in hearts with and without RV hypertrophy and failure.

\section{Methods:}

Wistar rats were subjected to pulmonary trunk banding to induce compensated RV hypertrophy $(n=32)$ or manifest RV failure $(n=32)$. Rats without banding served as healthy controls $(n=30)$. The hearts were excised and perfused in a Langendorff system and subjected to iloprost, treprostinil, epoprostenol or MRE-269 in increasing concentrations. The effect on RV function was evaluated using a balloon-tipped catheter inserted into the RV.

\section{Results:}

In control hearts iloprost, treprostinil and MRE-269, improved RV function. The effect was, however, absent in hearts with RV hypertrophy and failure. Treprostinil and MRE-269 even impaired RV function in hearts with manifest RV failure. 


\section{Conclusion:}

Iloprost, treprostinil and MRE-269 improved RV function in the healthy rat heart. RV hypertrophy abolished the positive inotropic effect and in the failing right ventricle, MRE-269 and treprostinil impaired RV function. This may be related to changes in prostanoid receptor expression and reduced coronary flow reserve in the hypertrophic and failing right ventricle.

Key words: prostacyclin, contractility, right ventricular failure, prostanoid receptors, pulmonary arterial hypertension

\section{Introduction}

Prostacyclins have since the 80 's been a cornerstone in the treatment of pulmonary arterial hypertension (PAH) owing to effective vasodilatory, antiproliferative and anti-thrombotic properties. ${ }^{1-3}$ Despite optimal drug therapy, PAH remains a devastating disease leading to impaired quality of life and premature death. ${ }^{4}$ Although PAH originates in the pulmonary vasculature, prognosis is closely associated with progression of right ventricular (RV) dysfunction and failure. The right ventricle suffers from sustained pressure overload, leading to hypertrophy, fibrosis and ultimately dilatation and failure, leaving RV failure the most common cause of death in patients with $\mathrm{PAH}{ }^{5,6}$

The inotropic effects of prostacyclin analogues in the right ventricle have only been investigated in a few previous studies. ${ }^{7-11}$ Kemming and collegues reported increased RV contractility in healthy pigs when subjected to epoprostenol and iloprost inhalation ${ }^{11}$ while others have investigated them in several different models for RV failure. ${ }^{7,9,10,12}$ However, models with unfixed afterload make it 
difficult to separate direct effects on the heart from those resulting in changes in the systemic and pulmonary circulation.

While prostacyclins are potent activators of the IP receptor, they will to varying degrees activate other prostanoid receptors. ${ }^{13}$ This prompted the development of the IP receptor specific drug, selexipag. ${ }^{14}$ The eight G-protein coupled prostanoid receptor subtypes work through different subcellular pathways (Gs, Gi, Gq). They are divided into subfamilies based on their ability to relax or contract smooth muscle. ${ }^{13,15}$ The prostacyclin analogues, used in the treatment of PAH, have diverse affinity and selectivity for the receptor subtypes. ${ }^{16,17}$ The distribution and function of these different receptor subtypes in the pulmonary vasculature have been investigated in recent years. ${ }^{16,18,19}$ The distribution in the right ventricle and its influence on the effect of the prostacyclins on the right heart remains, however, to be characterized.

In the present study we investigated the direct effects of iloprost, treprostinil, epoprostenol and MRE-269, the metabolite from selexipag, on RV function in the normal right ventricle and in a model of pressure overload-induced RV hypertrophy and failure. Choosing the isolated perfused heart model not only allowed us to test a wide dose range, but also excluded potential influence from the pulmonary and systemic circulation. We also investigated the role of the different prostanoid receptors in the right ventricle to help further characterize the myocardial action of prostacyclin mimetics. 


\section{Methods}

Outbred, male, Wistar rats were used in the experiments $(n=149)$. The rats were housed in pairs, allowed free access to water and standard rat chow and subjected to a 12-hour light-dark cycle. All experiments were performed in concordance with the Guide for the Care and Use of Laboratory Animals $(\mathrm{NIH}, 2011)^{20}$ and were approved by the Danish Animal Experiments Inspectorate (Authorization number: 2012-15-2934-00384). Method details are provided in the supplementary material online.

\section{Rat model of RV hypertrophy and failure}

Anesthesia was induced with $7 \%$ sevofluran and maintained with $3.5 \%$ sevoflurane in a mixture of $\mathrm{O}_{2} 1 \mathrm{~L} / \mathrm{min}$ and $\mathrm{N}_{2} \mathrm{O} 0.5 \mathrm{~L} / \mathrm{min}$. To reduce post-operative pain, buprenorphine was injected subcutaneously $(0.12 \mathrm{mg} / \mathrm{kg})$ during the procedure and applied to the drinking water $(7.4 \mu \mathrm{g} / \mathrm{mL})$ for three days postoperatively.

RV hypertrophy and failure were induced by pulmonary trunk banding (PTB) as previously described. ${ }^{8,21}$ The banding clip was applied in rats $(90 \pm 5 \mathrm{~g})$ and compressed to an inner diameter of $1.0 \mathrm{~mm}(\mathrm{n}=32)$ or $0.5 \mathrm{~mm}(\mathrm{n}=32)$. The rats were left for 7 weeks generating either $\mathrm{RV}$ hypertrophy (HYP) or manifest RV failure (FAIL). Rats without banding served as healthy controls $(\mathrm{CON})$.

\section{Echocardiography}

Before isolating the hearts, RV hypertrophy and function were evaluated using a Vevo 2100 echocardiographic system (Visual Sonics, Toronto, Canada) with a $21 \mathrm{MHz}$ linear array 
transducer. All analyses were made during expiration and are presented as the mean of three consecutive measurements.

\section{The isolated perfused heart model - Langendorff}

Anaesthesia was induced with a subcutaneous injection of a mix of midazolam, fentanyl citrate and fluanisone. The aorta was cannulated and retrograde perfusion was initiated before cutting out the heart. It was connected to a pressure-controlled Langendorff system as previously described. ${ }^{22}$ Krebs-Henseleit buffer was used as perfusion media, gassed with $95 \% \mathrm{O}_{2}$ and $5 \% \mathrm{CO}_{2}$ to keep the $\mathrm{pH}$ at 7.4 and the heart oxygenated.

RV hemodynamic parameters were monitored using a fluid-filled balloon introduced into the right ventricle and connected to a pressure transducer.

Coronary flow rate was measured using an in-line flow probe as an integrated part of the modified Langendorff setup (Type 2.5SB, Transonic System Inc. Ithaca, NY, USA). Coronary flow reserve (CFR) was estimated as $\mathrm{CFR}=\mathrm{CF}_{\max } / \mathrm{CF}_{\text {baseline }}$ after coronary flow was normalized to the weight of the heart. $\mathrm{CF}_{\max }$ : the maximum flow reached with prostacyclin mimetic administration was used

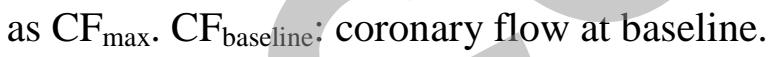

\section{Study design}

\section{Effects of prostacyclins on RV function}

Control $(n=30)$, hypertrophic $(n=32)$ and failing hearts $(n=32)$ were mounted in the Langendorff system and after 20-30 min of stabilization, each heart was perfused with iloprost $(0.02-6 \mathrm{ng} / \mathrm{mL})$, treprostinil (0.5-150 ng/mL), epoprostenol (0.06-20 ng/mL) or MRE-269 (30-10000 ng/mL). The hearts were perfused with each concentration for $10 \mathrm{~min}$ followed by $5 \mathrm{~min}$ perfusion of 
dobutamine $(0.1 \mu \mathrm{g} / \mathrm{mL})$ to test the contractile reserve of each isolated heart. Iloprost, treprostinil, epoprostenol and selexipag are all clinically available agents used in the treatment of pulmonary arterial hypertension. MRE-269, the active metabolite of selexipag, is approved only for experimental use.

\section{Coronary artery dilatation and RV function}

A potential association between coronary artery dilatation and RV function was investigated in additional two sets of experiments. One set of healthy hearts $(n=7)$ was subjected to treprostinil perfusion as described above, while keeping the flow constant at $13 \mathrm{~mL} / \mathrm{min}$ throughout the experiment. As the hearts were perfused with increasing concentrations of treprostinil, causing a gradual coronary vasodilation, the perfusion pressure was manually decreased keeping the coronary flow at $13 \mathrm{~mL} / \mathrm{min}$. At the end of the protocol the hearts were perfused with a dose of dobutamine to verify the ability to induce an inotropic response despite a constant coronary flow and a decreasing perfusion pressure.

Another set of healthy $(n=8)$, hypertrophic $(n=8)$ and failing $(n=8)$ rat hearts were perfused with the vasodilator, sodium nitroprusside (Nitropress ${ }^{\circledR}$, Hospira, Inc., Lake Forest, USA) (0.125-0.5 $\mu \mathrm{g} / \mathrm{mL}$ ), to investigate the effect of coronary vasodilation by a pure vasodilator on RV function.

\section{Expression of prostanoid receptors in the right ventricle}

RV tissue excised from healthy hearts $(n=8)$, hearts with RV hypertrophy $(n=8)$ and hearts with RV failure ( $n=8$ ) was snapped frozen in liquid nitrogen and cDNA was synthesized from RNA isolated from the RV tissue. Primers used in quantitative polymerase chain reaction (qPCR) were designed for the $\beta$-myosin heavy chain ( $\beta$-MHC), sarco/endoplasmatic reticulum $\mathrm{Ca}^{2+}$-ATPase 2 (SERCA-2) and the rat prostanoid receptors IP, $\mathrm{EP}_{1}, \mathrm{EP}_{2}, \mathrm{EP}_{3}, \mathrm{EP}_{4}, \mathrm{DP}_{1}$, TP and FP genes (Table 
s1, supplementary material). The level of mRNA was normalized to the reference gene, glyceraldehyde 3-phosphate dehydrogenase (GAPDH).

\section{Prostanoid receptors and RV function}

In a subset of experiments, healthy rat hearts were perfused with increasing concentrations of treprostinil $(0.5-150 \mathrm{ng} / \mathrm{mL})$ together with commercially available antagonists for the $\mathrm{DP}_{1} \quad(\mathrm{n}=8)$, $\mathrm{EP}_{2}(\mathrm{n}=8)$ or IP receptor $(\mathrm{n}=8)$. The aim was to investigate the influence of each receptor subtype on the effect of treprostinil in the right ventricle. After stabilization, the hearts were perfused with the antagonist alone for $10 \mathrm{~min}$, followed by increasing concentrations of treprostinil. The concentration of the receptor antagonist was kept constant during treprostinil perfusion.

\section{Statistics}

Unless otherwise stated, normally distributed data are presented as means \pm SD. Data were tested for normal distribution using normality test. Significance of difference was evaluated using 1-way ANOVA for repeated measurements followed by a relevant multiple comparisons test, 2-way ANOVA or Student's t-test. Observations not normally distributed were tested with equivalent non-parametric tests. The $\mathrm{p}$ value of $<0.05$ was considered to represent statistical significance. All data were analyzed using GraphPad Prism (version 6.0, GraphPad Software, Inc., San Diego, CA).

\section{Results}

\section{RV hypertrophy and failure}

Banding resulted in pressure overload to the right ventricle, demonstrated by more than a 2 -fold increase in baseline RV developed pressure (RVDP) compared with control hearts (Figure 1A). 
Progression of RV hypertrophy was related to the severity of PTB, shown by an increased right ventricle weight/tibia length in the HYP group, with an even further increase in the FAIL group (Figure 1B). Tricuspid annular plane systolic excursion (TAPSE) was decreased in the HYP group compared with the control group and in the FAIL group compared with both controls and HYP (CON vs. HYP, mm: $2.0 \pm 0.15$ vs. $1.5 \pm 0.17, \mathrm{p}<0.0001$, CON vs. FAIL: $2.0 \pm 0.15$ vs. $1.1 \pm 0.16$, p<0.0001, HYP vs. FAIL: $1.5 \pm 0.17$ vs. $1.1 \pm 0.16$, p<0.0001, 1-way ANOVA) (Figure 1C).

Cardiac output was preserved in the HYP group, contrary to the FAIL group, which had a significantly lower cardiac output compared with both the control group and the HYP group (Figure 1D).

To assess the effect of PTB on genes related to hypertrophy and heart failure we determined the expression of $\beta$-MHC and SERCA-2 mRNA in the RV. Analysis revealed up-regulation of $\beta$ MHC in the failing right ventricle and a down-regulation of SERCA-2 in the hypertrophic and failing right ventricle compared to controls (Figure 1E-F). Furthermore, almost half of the rats in the FAIL group presented with clinical manifestations of severe RV failure (Table 1).

\section{Contractile reserve of the right ventricle}

To assess the contractile reserve of the right ventricle, all hearts were perfused with dobutamine at the end of the protocol. Dobutamine elevated heart rate in all three groups (Figure s1A, supplementary material) and caused an increase in $\mathrm{dP} / \mathrm{dtmax}(\Delta \mathrm{dP} / \mathrm{dtmax}, \mathrm{mmHg} / \mathrm{sec}$ : $\mathrm{CON}$ vs. FAIL: $2284 \pm 1225$ vs. $915 \pm 823$, p<0.0001, HYP vs. FAIL: $2037 \pm 1354$ vs. $915 \pm 823$, p<0.001, 1 way ANOVA). Dobutamine also increased RV developed pressure (RVDP) in the controls and the hypertrophic hearts, but decreased RVDP in the failing hearts ( $\triangle \mathrm{RVDP}$, mmHg: CON vs. FAIL: $26 \pm 17$ vs. $-17 \pm 20, \mathrm{p}<0.0001$, HYP vs. FAIL: $17 \pm 24$ vs. $-17 \pm 20, \mathrm{p}<0.0001,1$-way ANOVA). 
There was no significant difference in the increase in dP/dtmax and RVDP between controls and hypertrophic hearts (Figure s1B-C supplementary material).

\section{Coronary flow reserve}

When normalized to the weight of the heart, coronary flow reserve was reduced in the hypertrophic hearts and even lower in the failing hearts, compared to controls (CON vs. HYP: $1.9 \pm 0.6$ vs. $1.5 \pm 0.3, \mathrm{p}<0.05$, CON vs. FAIL: $1.9 \pm 0.6$ vs. $1.2 \pm 0.2, \mathrm{p}<0.0001$, HYP vs. FAIL: $1.5 \pm 0.3$ vs. $1.2 \pm 0.2, \mathrm{p}<0.01,1$-way ANOVA). There was no difference in baseline coronary flow between the groups when normalized to the heart weight.

\section{Effects of iloprost on RV function}

Iloprost increased coronary flow in all three groups of isolated hearts $(\mathrm{CON}$ : p<0.0001, HYP: $\mathrm{p}=0.0001$, FAIL: $\mathrm{p}=0.0032$, 1-way ANOVA). The increase was, however, less pronounced in the HYP group and even lower in the FAIL group (Figure 2A).

Iloprost improved RV function in the control hearts, demonstrated by an increase in RVDP, $\mathrm{dP} / \mathrm{dtmax}$ and rate pressure product $(\mathrm{RPP})(\mathrm{p}=0.046, \mathrm{p}=0.035$ and $\mathrm{p}=0.015$, respectively, 1 -way ANOVA).

In the HYP group, iloprost did not alter RV function and in the FAIL group, though we observed a trend towards a reduction in RVDP ( $\mathrm{p}=0.061$, 1-way ANOVA) (Figure 2B-D).

Iloprost did not alter heart rate in any of the groups. 


\section{Effects of treprostinil on RV function}

Perfusion with increasing concentrations of treprostinil increased coronary flow in the control hearts. The increase was lower in hearts with hypertrophic and failing right ventricle. (CON: p<0.0001, HYP: p=0.0008, FAIL: p=0.017, 1-way ANOVA) (Figure 3A).

In the controls, treprostinil improved RV function, increasing RVDP, dP/dtmin and RPP $(\mathrm{p}=0.045$, $\mathrm{p}=0.01, \mathrm{p}=0.002$, respectively, 1-way ANOVA). The effect was mainly evident for the two lowest concentrations, comparable to doses used in the clinic. Higher concentrations blunted the response. Treprostinil had a small, non-significant positive effect on RV function in the HYP group when administered in the lowest concentration. Increasing concentrations reduced RVDP, dP/dtmax and RPP below the baseline value $(\mathrm{p}=0.005, \mathrm{p}=0.03, \mathrm{p}=0.005$, respectively, 1 -way ANOVA)

In the failing right ventricle, treprostinil impaired RV function by reducing RVDP ( $\mathrm{p}=0.002,1$ way ANOVA) (Figure 3B-D). Treprostinil elevated heart rate in the failing right ventricle ( $\mathrm{p}=0.034$, 1-way ANOVA), but heart rate was unaltered in the controls and the hypertrophic hearts.

\section{Effects of epoprostenol on RV function}

Epoprostenol elevated coronary flow in all hearts (CON p<0.0001, HYP p=0.0009, FAIL $\mathrm{p}<0.0001,1$-way ANOVA). The increase was lower in the HYP group and lowest in the FAIL group (Figure 4A).

Epoprostenol improved RVDP $(\mathrm{p}=0.13)$ and $\mathrm{dP} / \mathrm{dtmax}(\mathrm{p}=0.06)$ in the control group (Figure 4BD), however it did not reach statistical significance. There was no effect of epoprostenol on the hypertrophic and failing hearts.

Epoprostenol did not alter heart rate in any of the groups. 


\section{Effects of MRE-269 on RV function}

In controls and to a lesser extent in hypertrophic hearts, MRE-269 increased coronary flow rate. The increase in the FAIL group was non-significant (CON $p<0.0001$, HYP $p=0.0009$, FAIL $\mathrm{p}=0.074,1$-way ANOVA) (Figure 5A).

Perfusion with MRE-269 improved RV performance in the control hearts measured by $\mathrm{dP} / \mathrm{dtmax}$, RPP and RVDP ( $\mathrm{p}=0.003, \mathrm{p}=0.035, \mathrm{p}=0.085$, respectively, 1 -way ANOVA). In the HYP and the FAIL groups, MRE-269 impaired RV function markedly, when administered in supra-clinical concentrations (RVDP HYP: p<0.0001, RVDP FAIL: $\mathrm{p}<0.0001$, 1-way ANOVA) (Figure 5B-D). MRE-269 did not alter heart rate in any of the groups.

\section{Coronary artery dilatation and RV function}

Treprostinil perfusion of control hearts, while keeping coronary flow constant, caused a decrease in $\mathrm{RV}$ developed pressure, $\mathrm{dP} / \mathrm{dtmax}$ and $\mathrm{RPP}(\mathrm{p}=0.006, \mathrm{p}=0.01$ and $\mathrm{p}=0.006$, respectively, 1 -way ANOVA). Perfusion with dobutamine, however, increased RVDP, dP/dtmax and RPP (Figure s2, supplementary material).

Perfusion of control and hypertrophic hearts in the pressure-controlled setup with the vasodilator, sodium nitroprusside, increased coronary flow rate (CON p=0.001, HYP p<0.0001), RVDP (CON $\mathrm{p}=0.006$, HYP $\mathrm{p}<0.0001)$ and $\mathrm{dP} / \mathrm{dtmax}(\mathrm{CON} \mathrm{p}=0.024$, HYP $\mathrm{p}<0.0001)$. In the failing hearts, however, the increase in coronary flow was less pronounced and there was no effect on RVDP (FAIL $\mathrm{p}=0.87$ ) and $\mathrm{dP} / \mathrm{dtmax}(\mathrm{FAIL} \mathrm{p}=0.56)$ in this group (Figure $\mathrm{s} 3$, supplementary material).

\section{Prostanoid receptors in the right ventricle}

Messenger RNA expression analysis revealed that all eight prostanoid receptor subtypes were expressed in the right ventricle from controls. In the hypertrophic right ventricle there was an 
elevated expression of the $\mathrm{EP}_{1}, \mathrm{EP}_{3}, \mathrm{EP}_{4}$, IP and $\mathrm{TP}$ receptor and a reduced expression of the $\mathrm{DP}_{1}$ receptor. In the failing right ventricle the expression of the $\mathrm{EP}_{2}, \mathrm{EP}_{3}$ and IP receptor was elevated, while the $\mathrm{EP}_{4}$ and $\mathrm{DP}_{1}$ were reduced. Expression of the $\mathrm{EP}_{1}$ and $\mathrm{TP}$ receptor was not significantly altered (Figure 6).

Perfusion with the IP receptor antagonist, RO1138452, effectively inhibited the effect of treprostinil on coronary flow. It resulted in a rightward shift of the concentration-response curve when RO1138452 was added to the perfusion media (Figure 7A). The effect on RV function was also antagonized by RO1138452, causing a reduction in RVDP (Figure 7B). Perfusion with the $\mathrm{DP}_{1}$ receptor antagonist, $\mathrm{BW} \mathrm{A} 868 \mathrm{C}$, and the $\mathrm{EP}_{2}$ receptor antagonist, PF04418948, failed to alter the effect of treprostinil (Figure s4, supplementary material).

\section{Discussion}

This study is to our knowledge the first to investigate and compare the direct effects of four prostacyclin mimetics on RV function in a well-established model of RV hypertrophy and failure. The drugs tested are used clinically for the treatment of PAH. We found that administration of iloprost, treprostinil and MRE-269 improved RV function in healthy control hearts. This effect, however, was absent in hearts with RV hypertrophy and in hearts with manifest RV failure. Treprostinil and MRE-269 even impaired RV function in hearts with RV failure.

\section{RV hypertrophy and failure}

With pulmonary trunk banding we created two groups of rats; one with RV hypertrophy and one with manifest RV hypertrophy and failure. Rats subjected to the severe banding developed RV hypertrophy and manifest failure, demonstrated by a major increase in RV pressures and RV 
weight, a reduction in TAPSE and cardiac output and altered expression of genes related to hypertrophy and failure. ${ }^{23,24}$ These findings are comparable to both animals and humans with decompensated RV hypertrophy and failure ${ }^{5,21,25,26}$. Rats subjected to the mild banding presented with elevated RV pressures, increased RV weight, reduced TAPSE, but preserved cardiac output. This agrees with previous studies ${ }^{25,27}$ and suggests an adaptive remodeling of the right ventricle with preserved systolic function.

Using this well-established method we were able to separate the rats into 3 distinct groups. It allowed us to investigate and compare the effects of prostacyclin mimetics in the healthy right ventricle, the hypertrophic and the failing right ventricle.

\section{Effects of iloprost, treprostinil, epoprostenol and MRE-269 on RV function}

In healthy control hearts, all four agents doubled the coronary flow. Iloprost, treprostinil and MRE-269 improved RV function, however only treprostinil was effective in concentrations comparable to those used for $\mathrm{PAH}$ patients. The effect of epoprostenol did not reach statistical significance, which agrees with previous studies, showing a tendency towards epoprostenol being less effective than iloprost at increasing contractility. ${ }^{11,28}$

The differences observed among the agents may be related to their heterogeneous affinity and activity at the prostanoid receptors. Iloprost has a high affinity for the $\mathrm{EP}_{1}$ and IP receptor, whereas treprostinil has a high affinity for $\mathrm{DP}_{1}$ and $\mathrm{EP}_{2}$ receptors, though slightly less at the IP

receptor. ${ }^{16,29}$ In this study we were able to abolish the effect of treprostinil on RV function with a selective IP receptor antagonist, suggesting that the IP receptor plays a role in mediating the function of the right ventricle. Previous studies have suggested an anti-hypertrophic effect of the IP receptor in the heart, ${ }^{30,31}$ which may explain the major up-regulation of this receptor in the hypertrophic right ventricle, but a role in RV function has to our knowledge not been demonstrated until now. Given the IP receptor plays a role in RV function, one might think that the selective IP 
receptor agonist, MRE-269, would be the more potent agent. However, recent data suggest that MRE-269 may affect a non-typical IP receptor and/or is not completely selective to the IP receptor in rats. ${ }^{19}$

In the hearts with hypertrophic right ventricle we found no effect of iloprost, treprostinil and epoprostenol, whereas MRE-269 had a small negative effect on RV function. In hearts with manifest RV failure the negative effect of MRE-269 was more pronounced and also treprostinil had a small negative effect on RV function. It suggests that the effect of the prostacyclin mimetics is dependent of the degree of RV hypertrophy and failure. This agrees with the study of Riise and collegues who reported prostanoid-mediated inotropic responses to be attenuated in the failing human myocardium. ${ }^{32}$ The negative effect observed in this study was however only observed with high supra-clinical doses.

Reduced contractile reserve of the right ventricle may influence the effect of the prostacyclin mimetics in hearts with RV hypertrophy and failure. Decreased contractile reserve is associated with low response to pharmacological therapy in heart failure. ${ }^{33,34} \mathrm{We}$ tested the contractile reserve of the right ventricle by perfusion with dobutamine. The contractile reserve of the RV was preserved in the hypertrophic group despite high baseline RV pressures. In the failing RV, the contractile reserve was on the other hand reduced. The increase in $\mathrm{dP} / \mathrm{dtmax}$ was less pronounced and surprisingly, dobutamine decreased RVDP, indicating that the right ventricle was at the limit of its performance. $\beta 1$ adrenoceptors have previously been shown to be down-regulated in the process of heart failure ${ }^{46}$ and may result in the reduced contractile reserve and response to dobutamine perfusion in the hearts with manifest RV failure.

Reduced contractile reserve may partly explain the absent effect of the prostacyclin mimetics in the failing right ventricle. This, however, does not explain the attenuated effect in the hypertrophic right ventricle, where contractile reserve was preserved. The altered response in the hypertrophic 
and failing right ventricle could be related to the altered prostanoid receptor expression. The prostanoid receptors cross-react at the second messenger pathway level, and a change in composition of the receptors in the right ventricle may alter the interaction between the receptor subtypes. ${ }^{15,29}$ We observed an increased expression of the $\mathrm{EP}_{3}$ receptor in the hypertrophic right ventricle and the receptor was even more up-regulated in the failing right ventricle. The $\mathrm{EP}_{3}$ expression increased 3-fold compared to a 1.9-fold increase in IP receptor expression in the failing right ventricle. It has recently been shown that the $\mathrm{EP}_{3}$ receptor is a negative modulator of the IP receptor, ${ }^{35}$ and all prostacyclins will activate these receptors, with epoprostenol the most likely at clinical doses. ${ }^{13}$ Negative modulation of the IP receptor from the $\mathrm{EP}_{3}$ receptor may become more dominant in the failing right ventricle contributing to altered effect of the prostacyclin mimetics in the right ventricle. Indeed, $\mathrm{EP}_{3}$ receptors reduce the inotropy of beta-adrenergic stimulation in pigs, which may be an anti-ischemic mechanism in the heart. ${ }^{36}$

We found an increased expression of the $\mathrm{EP}_{4}$ receptor in the HYP group, but a decreased expression in the FAIL group. The $\mathrm{EP}_{4}$ receptor has previously demonstrated involvement in cardiac hypertrophy ${ }^{44,45}$ and may explain its up-regulation in the adaptive and hypertrophic response in the HYP group and its down-regulation in the failing, dilating and ischaemic right ventricle.

The expression of prostanoid receptors was evaluated by qPCR. A limitation of qPCR is that it measures messenger RNA levels, not protein levels. It will thus merely suggest changes in the level of protein and function than actually demonstrate it. ${ }^{37}$ The demonstration of the presence and level of the receptor protein was in this study limited by the lack of available specific antibodies.

The prostacyclins are known for their vasodilatory effects and in this study we were also able to demonstrate a marked increase in coronary flow, reflecting vasodilation of the coronary arteries. As the increase in contractility in the control hearts was accompanied by a simultaneous increase 
in coronary flow, we hypothesized that the mechanism of action of the prostacyclin mimetics on RV function, is at least partly, related to vasodilatation of the coronary arteries. To investigate this, we compared the effect of treprostinil on RV function under constant flow, and found that the positive effect of treprostinil on RV contractility was absent. This suggests that treprostinil works at least mainly via coronary artery dilation to increase contractility of the right ventricle rather than a direct inotropic effect on the cardiomyocytes. This could be explained by increased coronary micro-vascular filling and thus stretch of the sarcomeres and/or release of positive inotropic factors, leading to increased contractility. ${ }^{38-40}$ Also the nitroprusside experiments support the theory that coronary vasodilation could improve RV function. We found that nitroprusside, which can be considered a "pure" vasodilator, improved RV contractility in the control hearts and the hypertrophic hearts where the coronary flow was increased. This is in agreement with previous findings. ${ }^{41}$ In the failing hearts, where the increase in coronary flow was low, there was no effect on RV contractility. Further studies are, however, needed to fully confirm this mechanism. In contrast to the prostacyclin mimetics, dobutamine was able to increase RV contractility in the constant flow setup. This also indicates that the prostacyclin mimetics work through a different mechanism than the cardiac inotrope, dobutamine.

We found no difference in baseline coronary flow among the experimental groups. The response to prostacyclin administration was, however, attenuated in the hypertrophic and failing hearts, representing a reduced coronary flow reserve at the more advanced stage of RV hypertrophy and failure. Coronary flow reserve has shown to be decreased in PAH patients and correlated to the degree of RV dysfunction. ${ }^{42,43}$ Decreased cardiomyocyte/fibrosis ratio, reduced capillary density in the myocardium and increased diastolic stiffness are known characteristics of our PTB model. ${ }^{21}$ Given that the prostacyclin mimetics are dependent on increase in coronary flow to improve RV function, reduced coronary flow reserve, micro-vascular dysfunction, reduced capillary density 
and increased fibrosis may contribute to the attenuated effect of the prostacyclin mimetics on RV function in hearts with RV hypertrophy and failure.

To develop targeted treatments for patients with PAH and RV failure, it is necessary to fully characterize the effect of prostacyclin mimetics on RV function. The current study represents another step on this journey, though further studies delving deeper into the mechanism of action are needed.

\section{Limitations}

The study was carried out in rat hearts in an ex vivo experimental setup. Data from rat tissue may not be directly transferable to human tissue and pharmacologic effects may be different in the intact animal. This should be taken into consideration before clinical translation of the results.

The banding of the rats was applied on pre-adolescent rats (approximately $90 \mathrm{~g}$ ) to secure slow and gradually development of RV hypertrophy and failure. Initiation of disease development in preadolescents, however, does not apply to the majority of the clinical cases of RV failure. Though it is unlikely to play a major role as the evaluation was performed in the fully-grown rats, this should be taken into consideration when interpreting the results.

\section{Conclusion}

Iloprost, treprostinil and MRE-269 improved RV function in the isolated healthy rat heart. The positive inotropic effect of these compounds was abolished in RV hypertrophy and failure, and MRE-269 and treprostinil even impaired the function of the right ventricle when administered in supra-clinical concentrations. This may be related to changes in prostanoid receptor expression and reduced coronary flow reserve in the hypertrophic and failing right ventricle. 


\section{References}

1. Olschewski H, Rose F, Schermuly R, Ghofrani HA, Enke B, Olschewski A, Seeger W. Prostacyclin and its analogues in the treatment of pulmonary hypertension. Pharmacol Ther. 2004;102:139-153.

2. Olschewski H, Simonneau G, Galiè N, Higenbottam T, Naeije R, Rubin LJ, Nikkho S, Speich R, Hoeper MM, Behr J, Winkler J, Sitbon O, Popov W, Ghofrani HA, Manes A, Kiely DG, Ewert R, Meyer A, Corris PA, Delcroix M, Gomez-Sanchez M, Siedentop H, Seeger W, Aerosolized Iloprost Randomized Study Group. Inhaled iloprost for severe pulmonary hypertension. N Engl J Med. 2002;347:322-329.

3. Simonneau G, Barst RJ, Galiè N, Naeije R, Rich S, Bourge RC, Keogh A, Oudiz R, Frost A, Blackburn SD, Crow JW, Rubin LJ, Treprostinil Study Group. Continuous subcutaneous infusion of treprostinil, a prostacyclin analogue, in patients with pulmonary arterial hypertension: a double-blind, randomized, placebocontrolled trial. Am J Respir Crit Care Med. 2002;165:800-804.

4. Humbert M, Sitbon O, Chaouat A, Bertocchi M, Habib G, Gressin V, Yaïci A, Weitzenblum E, Cordier J-F, Chabot F, Dromer C, Pison C, Reynaud-Gaubert M, Haloun A, Laurent M, Hachulla E, Cottin V, Degano B, Jaïs X, Montani D, Souza R, Simonneau G. Survival in patients with idiopathic, familial, and anorexigenassociated pulmonary arterial hypertension in the modern management era. Circulation. 2010;122:156-163.

5. Haddad F, Doyle R, Murphy DJ, Hunt SA. Right ventricular function in cardiovascular disease, part II: pathophysiology, clinical importance, and management of right ventricular failure. Circulation. 2008;117:1717-1731.

6. Vonk-Noordegraaf A, Haddad F, Chin KM, Forfia PR, Kawut SM, Lumens J, Naeije R, Newman J, Oudiz RJ, Provencher S, Torbicki A, Voelkel NF, Hassoun PM. Right heart adaptation to pulmonary arterial hypertension: physiology and pathobiology. J Am Coll Cardiol. 2013;62:D22-33.

7. Zeineh NS, Bachman TN, El-Haddad H, Champion HC. Effects of acute intravenous iloprost on right ventricular hemodynamics in rats with chronic pulmonary hypertension. Pulm Circ. 2014;4:612-618.

8. Holmboe S, Andersen A, Vildbrad MD, Nielsen JM, Ringgaard S, Nielsen-Kudsk JE. Iloprost improves ventricular function in the hypertrophic and functionally impaired right heart by direct stimulation. Pulm Circ. 2013;3:870-879.

9. Rex S, Missant C, Segers P, Rossaint R, Wouters PF. Epoprostenol treatment of acute pulmonary hypertension is associated with a paradoxical decrease in right ventricular contractility. Intensive Care Med. 2008;34:179189.

10. Kerbaul F, Brimioulle S, Rondelet B, Dewachter C, Hubloue I, Naeije R. How prostacyclin improves cardiac output in right heart failure in conjunction with pulmonary hypertension. Am J Respir Crit Care Med. 2007; 175:846-850.

11. Kemming G, Kisch-Wedel H, Flondor M, Hofstetter C, Kreyling W, Thein E, Meisner F, Bruhn S, Zwissler B. Improved ventricular function during inhalation of $\mathrm{PGI}_{2}$ aerosol partly relies on enhanced myocardial contractility. Eur Surg Res. 2005;37:9-17.

12. Wauthy P, Abdel Kafi S, Mooi WJ, Naeije R, Brimioulle S. Inhaled nitric oxide versus prostacyclin in chronic shunt-induced pulmonary hypertension. J Thorac Cardiovasc Surg. 2003;126:1434-1441.

13. Clapp LH, Gurung R. The mechanistic basis of prostacyclin and its stable analogues in pulmonary arterial hypertension: Role of membrane versus nuclear receptors. Prostaglandins Other Lipid Mediat. 2015;

14. Simonneau G, Torbicki A, Hoeper MM, Delcroix M, Karlócai K, Galiè N, Degano B, Bonderman D, Kurzyna M, Efficace M, Giorgino R, Lang IM. Selexipag: an oral, selective prostacyclin receptor agonist for the treatment of pulmonary arterial hypertension. Eur Respir J. 2012;40:874-880.

15. Hirata T, Narumiya S. Prostanoid receptors. Chem Rev. 2011;111:6209-6230. 
16. Whittle BJ, Silverstein AM, Mottola DM, Clapp LH. Binding and activity of the prostacyclin receptor (IP) agonists, treprostinil and iloprost, at human prostanoid receptors: treprostinil is a potent DP1 and EP2 agonist. Biochem Pharmacol. 2012;84:68-75.

17. Benyahia C, Boukais K, Gomez I, Silverstein A, Clapp L, Fabre A, Danel C, Leséche G, Longrois D, Norel X. A comparative study of PGI2 mimetics used clinically on the vasorelaxation of human pulmonary arteries and veins, role of the DP-receptor. Prostaglandins Other Lipid Mediat. 2013;107:48-55.

18. Falcetti E, Hall SM, Phillips PG, Patel J, Morrell NW, Haworth SG, Clapp LH. Smooth muscle proliferation and role of the prostacyclin (IP) receptor in idiopathic pulmonary arterial hypertension. Am J Respir Crit Care Med. 2010;182:1161-1170.

19. Orie NN, Ledwozyw A, Williams DJ, Whittle BJ, Clapp LH. Differential actions of the prostacyclin analogues treprostinil and iloprost and the selexipag metabolite, MRE-269 (ACT-333679) in rat small pulmonary arteries and veins. Prostaglandins Other Lipid Mediat. 2013;106:1-7.

20. National Research Council (US) Committee for the Update of the Guide for the Care and Use of Laboratory Animals. Guide for the Care and Use of Laboratory Animals. 8 ed. Washington (DC): National Academies Press (US); 2011.

21. Andersen S, Schultz JG, Andersen A, Ringgaard S, Nielsen JM, Holmboe S, Vildbrad MD, de Man FS, Bogaard HJ, Vonk-Noordegraaf A, Nielsen-Kudsk JE. Effects of bisoprolol and losartan treatment in the hypertrophic and failing right heart. J Card Fail. 2014;20:864-873.

22. Løfgren B, Povlsen JA, Rasmussen LE, Støttrup NB, Solskov L, Krarup P-M, Kristiansen SB, Bøtker HE, Nielsen TT. Amino acid transamination is crucial for ischaemic cardioprotection in normal and preconditioned isolated rat hearts--focus on L-glutamate. Exp Physiol. 2010;95:140-152.

23. Hasenfuss G, Reinecke H, Studer R, Meyer M, Pieske B, Holtz J, Holubarsch C, Posival H, Just H, Drexler H. Relation between myocardial function and expression of sarcoplasmic reticulum $\mathrm{Ca}(2+)$-ATPase in failing and nonfailing human myocardium. Circ Res. 1994;75:434-442.

24. Lowes BD, Minobe W, Abraham WT, Rizeq MN, Bohlmeyer TJ, Quaife RA, Roden RL, Dutcher DL, Robertson AD, Voelkel NF, Badesch DB, Groves BM, Gilbert EM, Bristow MR. Changes in gene expression in the intact human heart. Downregulation of alpha-myosin heavy chain in hypertrophied, failing ventricular myocardium. J Clin Invest. 1997;100:2315-2324.

25. Andersen A, Povlsen JA, Bøtker HE, Nielsen-Kudsk JE. Right ventricular hypertrophy and failure abolish cardioprotection by ischaemic pre-conditioning. Eur J Heart Fail. 2013;15:1208-1214.

26. López-Candales A, Dohi K, Rajagopalan N, Edelman K, Gulyasy B, Bazaz R. Defining normal variables of right ventricular size and function in pulmonary hypertension: an echocardiographic study. Postgrad Med J. 2008;84:40-45.

27. Bogaard HJ, Natarajan R, Henderson SC, Long CS, Kraskauskas D, Smithson L, Ockaili R, McCord JM, Voelkel NF. Chronic pulmonary artery pressure elevation is insufficient to explain right heart failure. Circulation. 2009;120:1951-1960.

28. Kisch-Wedel H, Kemming G, Meisner F, Flondor M, Kuebler WM, Bruhn S, Koehler C, Zwissler B. The prostaglandins epoprostenol and iloprost increase left ventricular contractility in vivo. Intensive Care Med. $2003 ; 29: 1574-1583$.

29. Abramovitz M, Adam M, Boie Y, Carrière M, Denis D, Godbout C, Lamontagne S, Rochette C, Sawyer N, Tremblay NM, Belley M, Gallant M, Dufresne C, Gareau Y, Ruel R, Juteau H, Labelle M, Ouimet N, Metters KM. The utilization of recombinant prostanoid receptors to determine the affinities and selectivities of prostaglandins and related analogs. Biochim Biophys Acta. 2000;1483:285-293.

30. Ritchie RH, Rosenkranz AC, Huynh LP, Stephenson T, Kaye DM, Dusting GJ. Activation of IP prostanoid receptors prevents cardiomyocyte hypertrophy via cAMP-dependent signaling. Am J Physiol Heart Circ Physiol. 2004;287:H1179-85. 
31. Yuhki K-I, Kojima F, Kashiwagi H, Kawabe J-I, Fujino T, Narumiya S, Ushikubi F. Roles of prostanoids in the pathogenesis of cardiovascular diseases: Novel insights from knockout mouse studies. Pharmacol Ther. 2011;129:195-205.

32. Riise J, Nguyen CHT, Hussain RI, Dahl CP, Ege MS, Osnes J-B, Skomedal T, Sandnes DL, Levy FO, Krobert KA. Prostanoid-mediated inotropic responses are attenuated in failing human and rat ventricular myocardium. Eur J Pharmacol. 2012;686:66-73.

33. Dubois-Randé JL, Merlet P, Roudot F, Benvenuti C, Adnot S, Hittinger L, Duval AM, Syrota A, Castaigne A, Loisance D. Beta-adrenergic contractile reserve as a predictor of clinical outcome in patients with idiopathic dilated cardiomyopathy. Am Heart J. 1992;124:679-685.

34. Ramahi TM, Longo MD, Cadariu AR, Rohlfs K, Carolan SA, Engle KM, Samady H, Wackers FJ. Left ventricular inotropic reserve and right ventricular function predict increase of left ventricular ejection fraction after beta-blocker therapy in nonischemic cardiomyopathy. J Am Coll Cardiol. 2001;37:818-824.

35. Orie NN, Clapp LH. Role of prostanoid IP and EP receptors in mediating vasorelaxant responses to PGI2 analogues in rat tail artery: Evidence for Gi/o modulation via EP3 receptors. Eur J Pharmacol. 2011;654:258265.

36. Hohlfeld T, Zucker TP, Meyer J, Schrör K. Expression, function, and regulation of E-type prostaglandin receptors (EP3) in the nonischemic and ischemic pig heart. Circ Res. 1997;81:765-773.

37. Valasek MA, Repa JJ. The power of real-time PCR. Adv Physiol Educ. 2005;29:151-159.

38. Li YH, Yu B, Duan ZZ, Akinyi OM, Yu JH, Zhou K, Zhang Y, Gao XM. The coronary dilation effect of shen fu injection was mediated through NO. PLOS ONE. 2014;9:e92415.

39. Arnold G, Kosche F, Miessner E, Neitzert A, Lochner W. The importance of the perfusion pressure in the coronary arteries for the contractility and the oxygen consumption of the heart. Pflugers Arch Gesamte Physiol Menschen Tiere. 1968;299:339-356.

40. Gregg DE. Effect of coronary perfusion pressure or coronary flow on oxygen usage of the myocardium. Circ Res. 1963;13:497-500.

41. Bratkovsky SV, Aasum E, Riemersma RA, Myhre ESP, Larsen TS. Reduced coronary reserve in response to short-term ischaemia and vasoactive drugs in ex vivo hearts from diabetic mice. Acta Physiol (Oxf). 2006;186:171-177.

42. Skrok J, Shehata ML, Mathai S, Tomas MS, Singh S, Girgis RE, Mudd JO, Boyce D, Lechtzin N, Lima JA, Bluemke DA, Hassoun PM, Vogel-Claussen J. Coronary flow reserve correlates with right ventricular dysfunction and predicts right heart failure in patients with pulmonary arterial hypertension. J Cardiov Magn Reson. 2011;:329.

43. Vogel-Claussen J, Skrok J, Shehata ML, Singh S, Sibley CT, Boyce DM, Lechtzin N, Girgis RE, Mathai SC, Goldstein TA, Zheng J, Lima JAC, Bluemke DA, Hassoun PM. Right and left ventricular myocardial perfusion reserves correlate with right ventricular function and pulmonary hemodynamics in patients with pulmonary arterial hypertension. Radiology. 2011;258:119-127.

44. Mendez M, LaPointe MC. Trophic effects of the cyclooxygenase-2 product prostaglandin $\mathrm{E}_{2}$ in cardiac myocytes. Hypertension, 2002, vol. 39 (2 Pt 2), 382-388.

45. Miyatake S, Manabe-Kawaguchi H, Wantanbe K, Hori S, Aikawa N, Fukuda K. Prostaglandin E2 induces hypertrophic changes and suppresses alpha-skeletal actin gene expression in rat cardiomyocytes. J Cardiovasc Pharmacol. 2007;50(5), 548-554.

46. Triposkiadis, F., Karayannis, G., Giamouzis, G., Skoularigis, J., Louridas, G., \& Butler, J. (2009). The sympathetic nervous system in heart failure physiology, pathophysiology, and clinical implications. Journal of the American College of Cardiology, 54(19), 1747-1762. 


\section{Legends}

Figure 1. A-D: Influence of pulmonary trunk banding (PTB). Results are presented as means \pm SD. $* * * \mathrm{p}<0.001, * * * * \mathrm{P}<0.0001,1$-way ANOVA. Control, $\mathrm{n}=25 ;$ Hypertrophic, $\mathrm{n}=30 ;$ Failure, $\mathrm{n}=32$. E-F: Effect of PTB on the gene expression of SERCA-2 and $\beta$-MHC quantified by polymerase chain reaction, normalized to the reference gene, glyceraldehyde 3-phosphate dehydrogenase. Control $n=8$, Hypertrophic $n=8$, Failure $n=8$. Results are presented as mean $\pm 95 \%$ CI relative to mRNA level of controls, normalized to $1 . *^{* * *} \mathrm{p}<0.0001$, Student's t-test. RV: right ventricular. TAPSE: Tricuspid annular plane systolic excursion. SERCA-2: sarco/endoplasmatic reticulum $\mathrm{Ca}^{2+}$-ATPase. B-MHC: $\beta$-Myosin heavy chain. mRNA: messenger RNA.

Figure 2. Effects of iloprost on RV function in the isolated perfused heart. Control, $n=7$; Hypertrophic, $n=8$; Failure, $n=8$; Values are presented as relative to mean of baseline normalized to $1,+$ SD. $\dagger \mathrm{p}<0.05, \dagger \dagger \mathrm{p}<0.01,+\dagger \dagger \mathrm{p}<0.001$, $\uparrow \dagger \uparrow \dagger \mathrm{p}<0.0001$, compared to baseline. $* \mathrm{p}<0.05$, $* * \mathrm{p}<0.01, * * * \mathrm{p}<0.001, * * * * \mathrm{p}<0.0001$, between groups. RV: right ventricular.

Figure 3. Effects of treprostinil on RV function in the isolated perfused heart. Control, $n=8$; Hypertrophic, $n=8$; Failure, $n=8$. Values are presented as relative to mean of baseline normalized to $1,+$ SD. $\uparrow p<0.05, \dagger \dagger p<0.01$, $\dagger \dagger \uparrow \mathrm{p}<0.001$, compared to baseline. $* \mathrm{p}<0.05, * * \mathrm{p}<0.01$, $* * * \mathrm{p}<0.001, * * * * \mathrm{p}<0.0001$, between groups. RV: right ventricular.

Figure 4. Effects of epoprostenol on RV function in the isolated perfused heart. Control, $n=7$; Hypertrophic, $n=8$; Failure, $n=8$. Values are presented as relative to mean of baseline normalized to $1,+$ SD. $\dagger \mathrm{p}<0.05, \dagger \dagger \mathrm{p}<0.01, \dagger \dagger \uparrow \mathrm{p}<0.001$, compared to baseline. $* \mathrm{p}<0.05, * * \mathrm{p}<0.01$, $* * * \mathrm{p}<0.001, * * * * \mathrm{p}<0.0001$, between groups. RV: right ventricular. 
Figure 5. Effects of MRE-269 on RV function in the isolated perfused heart. Control, $n=8$; Hypertrophic, $n=8$; Failure, $n=8$. Values are presented as relative to mean of baseline normalized to $1+$ SD. $\dagger \mathrm{p}<0.05$, $\dagger \dagger \mathrm{p}<0.01$, $\dagger \dagger \dagger \mathrm{p}<0.001$, $\dagger \dagger \uparrow \dagger \mathrm{p}<0.0001$, compared to baseline. $* \mathrm{p}<0.05$, $* * \mathrm{p}<0.01, * * * \mathrm{p}<0.001, * * * * \mathrm{p}<0.0001$, between groups. $\mathrm{RV}$ : right ventricular.

Figure 6. Expression of mRNA for the prostanoid receptor subtypes in the RV, quantified by polymerase chain reaction. The data was normalized to the reference gene, glyceraldehyde 3phosphate dehydrogenase. Control, n=8; Hypertrophic, n=8; Failure, n=8. Results are presented as mean $\pm 95 \%$ CI relative to the mRNA level of the controls, normalized to 1 . ${ }^{*} \mathrm{p}<0.05$, $* * \mathrm{p}<0.01$, $* * * \mathrm{p}<0.001, * * * * \mathrm{p}<0.0001$, Student's t-test. RV : right ventricular. mRNA: messenger RNA.

Figure 7. Effects of increasing concentrations of treprostinil $(n=8)$ and the IP receptor antagonist, R01138452 $(0.5 \mu \mathrm{M}),(\mathrm{n}=8)$ on $\mathrm{A}$ : coronary flow, B: RVDP and C: heart rate. Values are presented as relative to mean of baseline, normalized to $1,+\mathrm{SD} . \dagger \mathrm{p}<0.05, \dagger \dagger \mathrm{p}<0.01, \uparrow \dagger \uparrow \mathrm{p}<0.001$, $+\dagger \dagger \dagger \mathrm{p}<0.0001$, compared to baseline. $* * * \mathrm{p}<0.001$, ****p $<0.0001$, between groups. RV: right ventricular. IPr: IP receptor. RVDP: Right ventricular developed pressure. 
Table 1: Animal characteristics.

\begin{tabular}{|c|c|c|c|}
\hline & Control & Hypertrophic & Failure \\
\hline & Mean \pm sd & Mean \pm sd & Mean \pm sd \\
\hline \multicolumn{4}{|l|}{ A) } \\
\hline Body weight at termination (g) & $333 \pm 10$ & $351 \pm 21 * * *$ & 312 \\
\hline $\mathrm{LV}+\mathrm{S}$ weight $(\mathrm{g})$ & $0.77 \pm 0.08$ & $0.82 \pm 0.09$ & \\
\hline Liver (g) & $12.4 \pm 0.9$ & $12.5 \pm$ & \\
\hline Spleen $(g)$ & $0.72 \pm 0.08$ & 0.19 & $0.77 \pm 0.09$ \\
\hline Kidney (g) & $2.2 \pm 0.3$ & & $* \dagger \dagger \dagger \dagger$ \\
\hline Intraperitoneal fluid (\% of group) & 0 & & 37.5 \\
\hline Nutmeg/stase liver (\% of group) & & 0 & 43.8 \\
\hline \multicolumn{4}{|l|}{ B) } \\
\hline Heart Rate (bpm) & & $379 \pm 22 * * * *$ & $333 \pm 28 * * * * \dagger \dagger \dagger \dagger$ \\
\hline Stroke volume (uL) & & $301 \pm 58$ & $199 \pm 54 * * * *+\dagger \dagger \dagger$ \\
\hline Peak velocity $(\mathrm{mm} / \mathrm{sec})$ & $868 \pm 83$ & $810 \pm 219 * *$ & $466 \pm 93 * * * * \dagger \dagger \dagger \dagger$ \\
\hline Pulsed wave tissue doppler (mm) & $4.1 \pm 0.6$ & $3.9 \pm 0.6$ & $3.2 \pm 0.6 * * * *+\dagger \dagger \dagger$ \\
\hline Pulmonary acceleration time (ms) & $29 \pm 7.3$ & $26 \pm 13.3 *$ & $25 \pm 4.9 *$ \\
\hline Coronary flow rate (mL/min) & $10 \pm 2.4$ & $12.7 \pm 1.7 * * * *$ & $16.1 \pm 2.6 * * * * \dagger \dagger \dagger \dagger$ \\
\hline Coronary flow rate $(\mathrm{mL} / \mathrm{min}) /$ heart weight $(\mathrm{g})$ & $11.9 \pm 2.5$ & $10.6 \pm 1.4$ & $10.7 \pm 2.2$ \\
\hline Coronary flow reserve & $1.9 \pm 0.6$ & $1.5 \pm 0.3 *$ & $1.2 \pm 0.2 * * * * \dagger \dagger$ \\
\hline
\end{tabular}

Table 1: Animal characteristics. A) Organ weights at termination. B) Hemodynamic values at baseline. Sd: standard deviation. $\mathrm{RV}$ : right ventricle, $\mathrm{LV}+\mathrm{S}$ : left ventricle+septum, $* \mathrm{P}<0.05$, ** $\mathrm{P}<0.01$, *** $\mathrm{P}<0.001, * * * *$ $\mathrm{P}<0.0001$ compared to control group. $\dagger \dagger \mathrm{P}<0.01, \dagger \dagger \dagger \dagger \mathrm{P}<0.0001$ compared to hypertrofic group. 
Table s1. Primer sequences used for qPCR

\begin{tabular}{|c|c|c|}
\hline Gene & Primer sequence $\left(5^{\prime} \rightarrow 3^{\prime}\right)$ & \\
\hline \multirow[t]{2}{*}{ EP1 } & Forward & ACTGCCACCTTCCTGTTGTT \\
\hline & Reverse & GCCCAAGGCTAATGAAACAC \\
\hline EP2 & Forward & CTTGTTCO \\
\hline \multirow[t]{2}{*}{ EP3 } & Forward & TGTCAG \\
\hline & Reverse & GGATCTTTCTTAGCAGCAGA \\
\hline \multirow[t]{2}{*}{ EP4 } & Forward & GCCACATACA \\
\hline & Reverse & GGCGGCGTA \\
\hline IP & Forward & ССТССАТСТТСТТСТG \\
\hline \multirow[t]{2}{*}{ DP1 } & Forward & CGGTAATAGGCTTCTCTGTGCT \\
\hline & & TCCACAAGTTTAAAGGCTCCAT \\
\hline \multirow[t]{2}{*}{ TP } & Forward & GACTGTGAGGTGGAGATGAT \\
\hline & & GCGTAGGTAGATGAGCAGTT \\
\hline \multirow[t]{2}{*}{ FP } & Forward & TCACGGGAGTCACACTTTTG \\
\hline & Reverse & TGAGTTCCCAGATGTGCAAG \\
\hline \multirow[t]{2}{*}{ SERCA-2a } & Forward & TACCAGCTGAGTCATTTCT \\
\hline & Reverse & CATTGCACATCTCTATGGG \\
\hline \multirow[t]{2}{*}{ 及-MHC } & Forward & GAGCTTCTAGACATGCTGCT \\
\hline & Reverse & TGGAGTTCTTCTCTTCTGGA \\
\hline \multirow[t]{2}{*}{ GAPDH } & Forward & TTCATTGACCTCAACTACAT \\
\hline & Reverse & GAGGGGCCATCCACAGTCTT \\
\hline
\end{tabular}



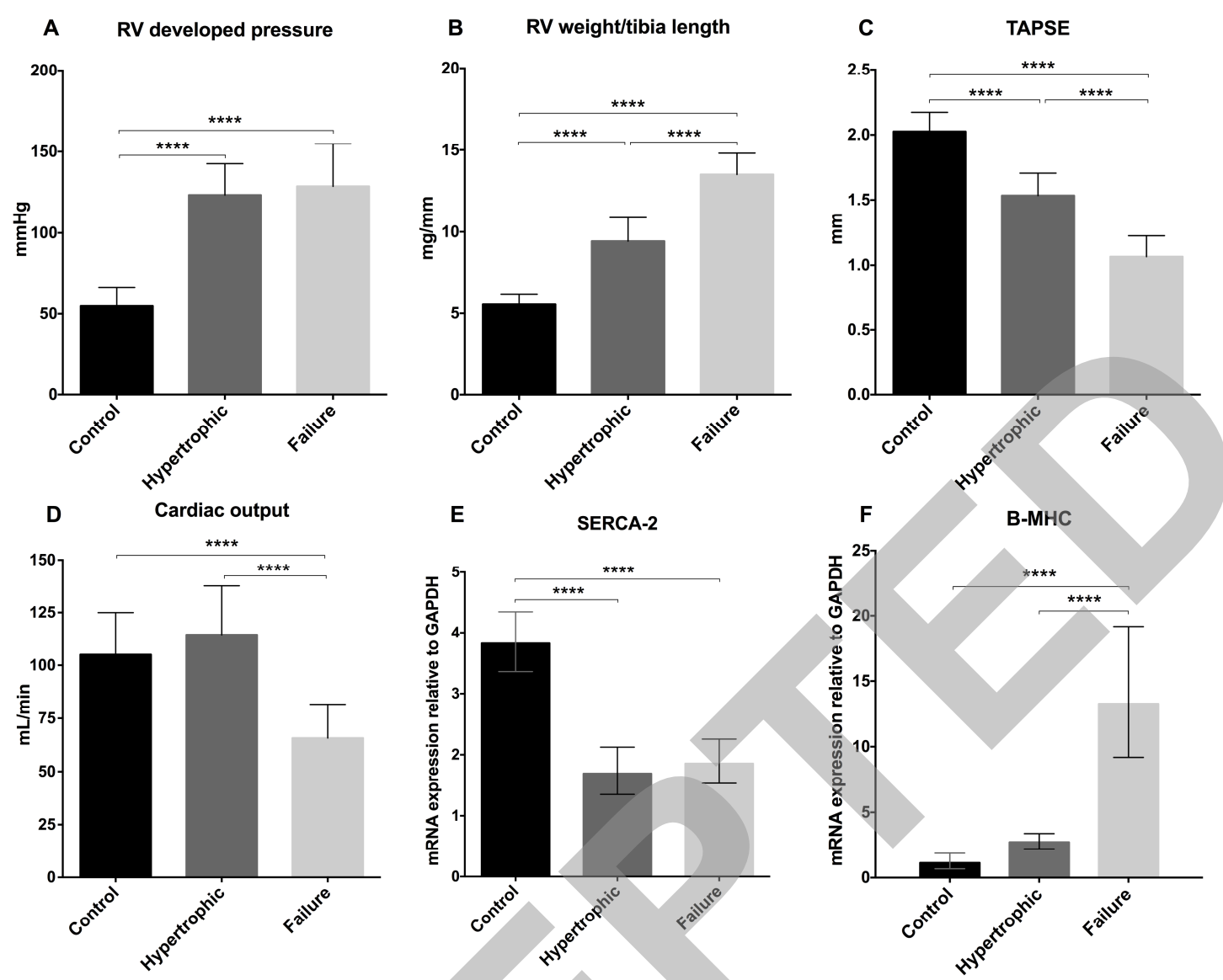
A

lloprost

Coronary flow
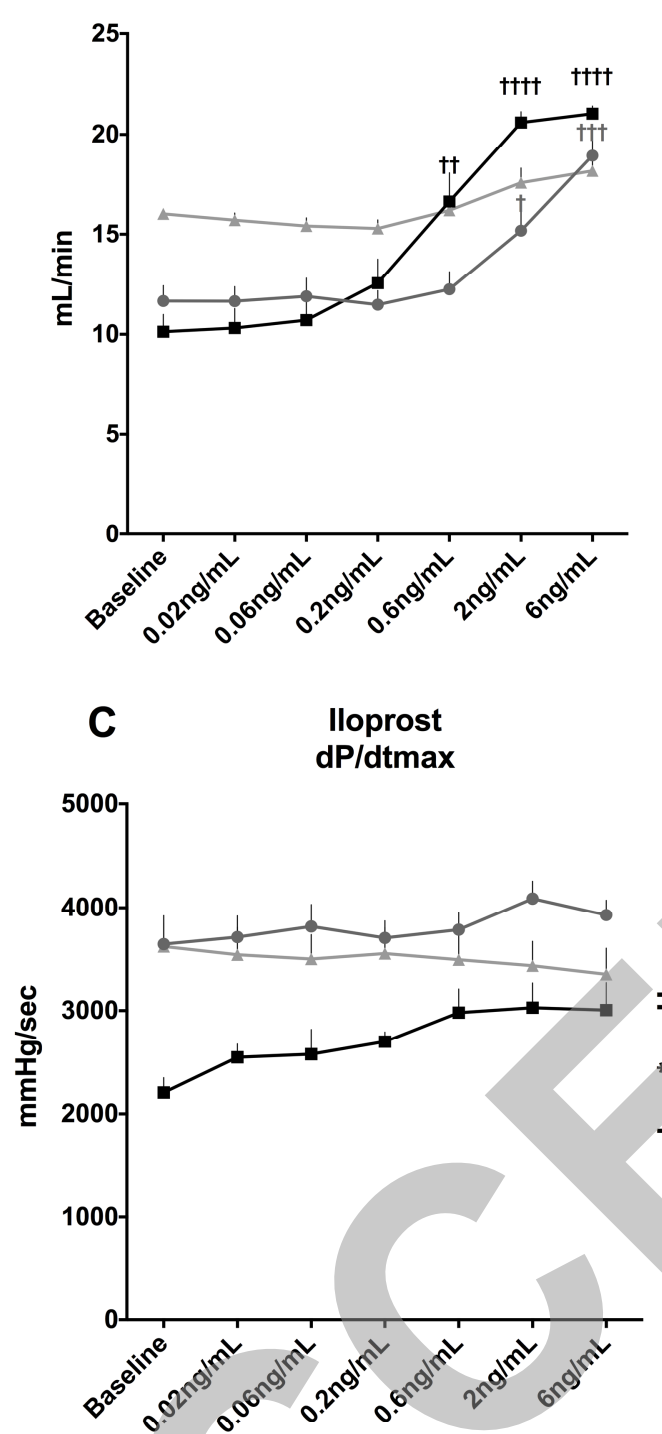

B lloprost

RV developed pressure

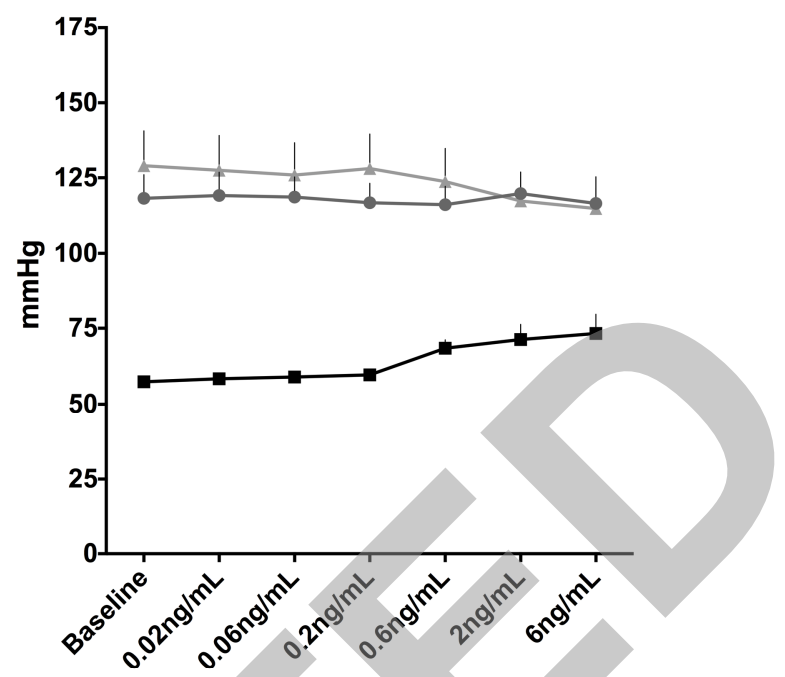

D lloprost

Rate Pressure Product

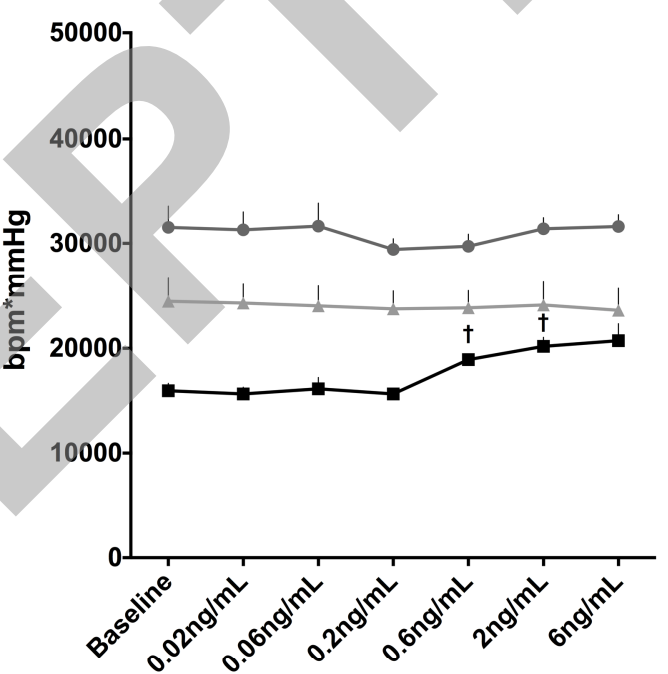

Control

Hypertrophic $\quad$ Failure 

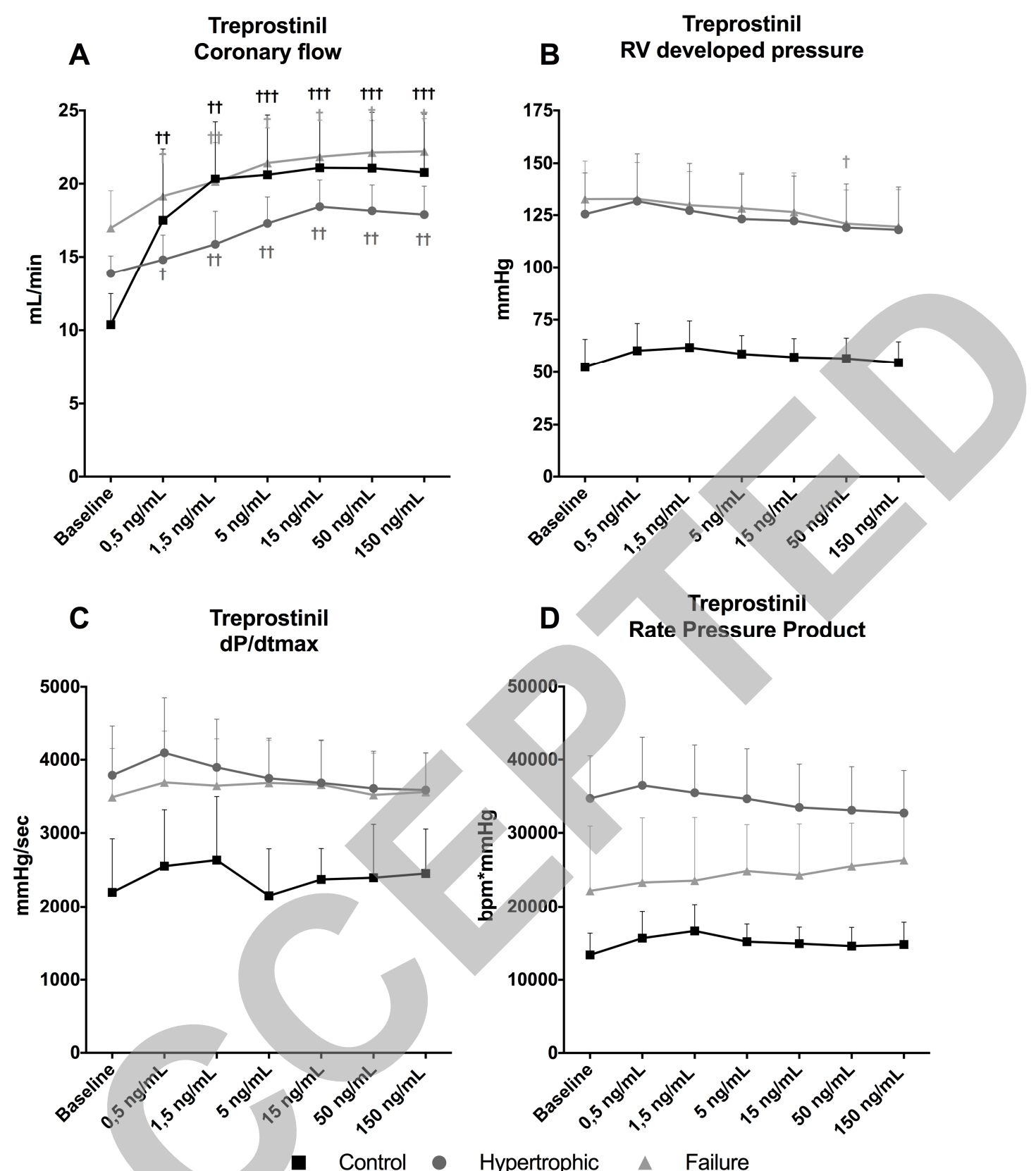

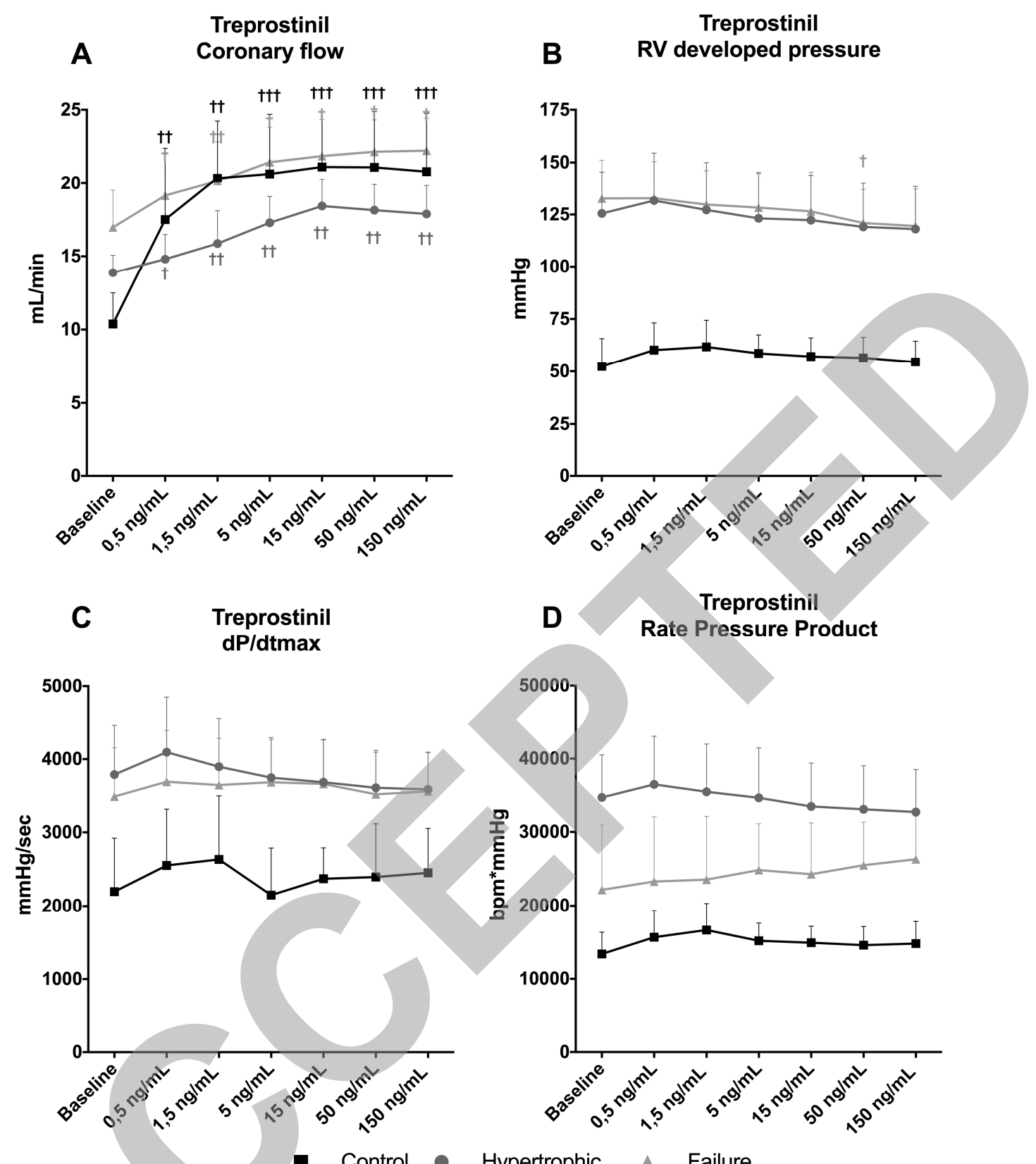

- Control - Hypertrophic $\triangle$ Failure 


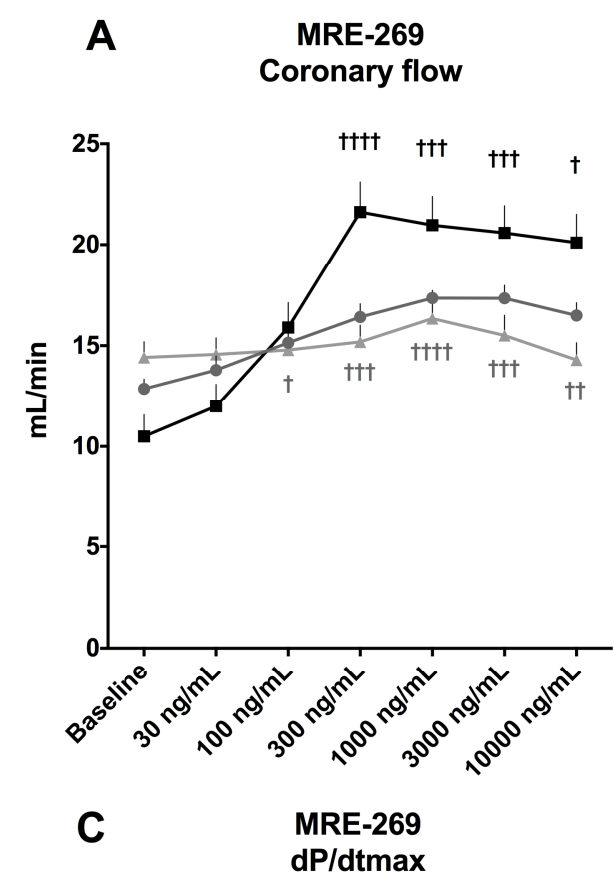

MRE-269
B $\quad$ RV developed pressure
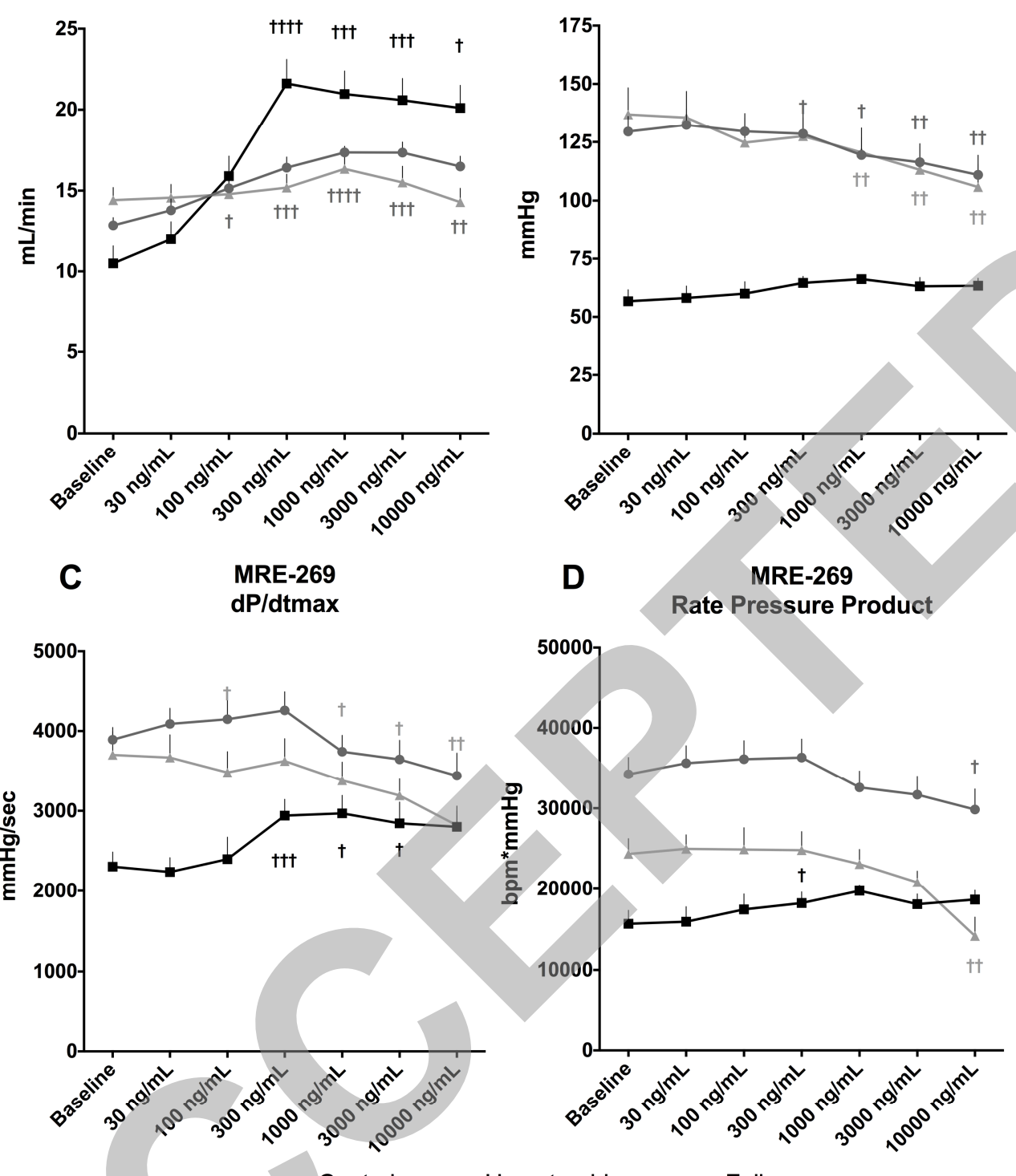

D

MRE-269

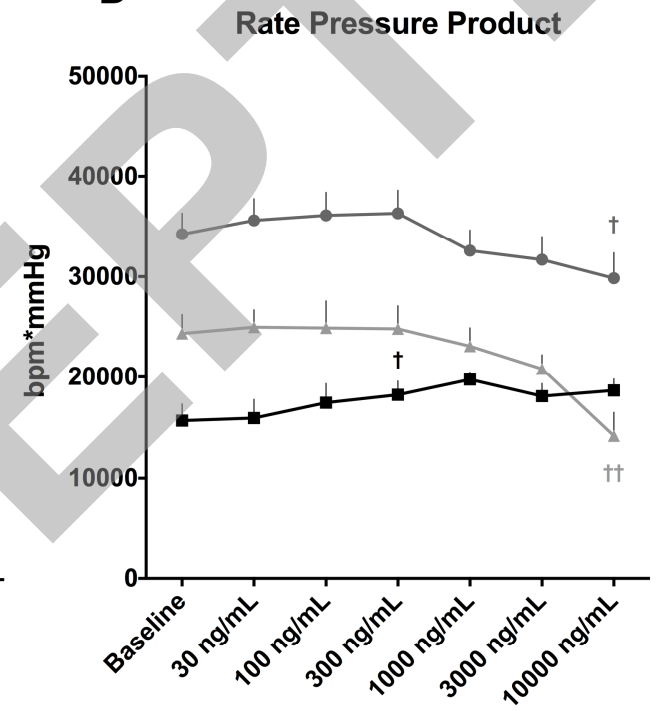

- Control - Hypertrophic $\Delta$ Failure 


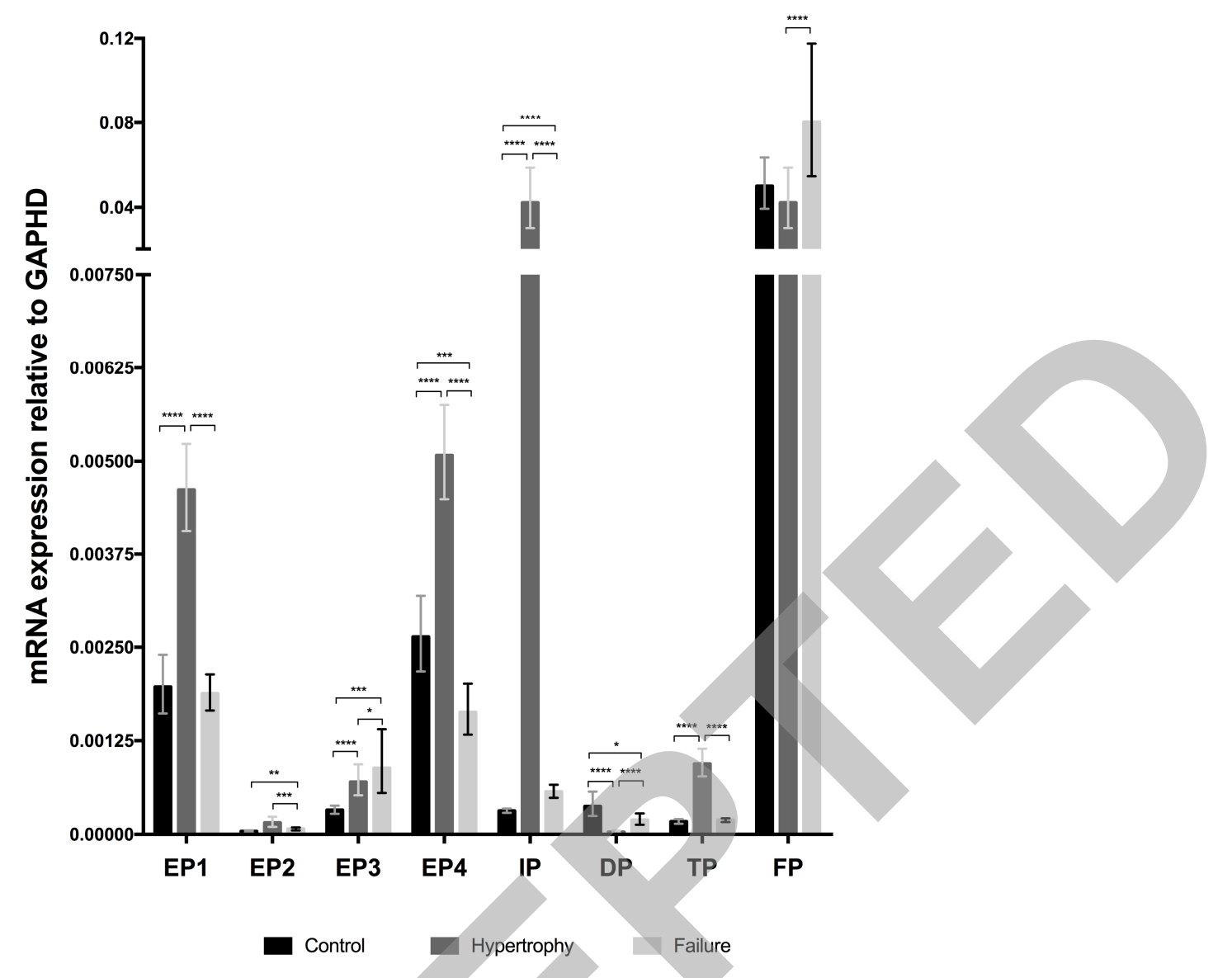


A Treprostinil + IP antagonist Coronary flow

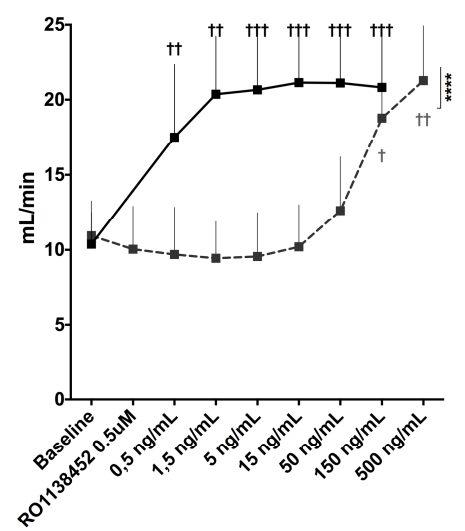

B Treprostinil + IP antagonist $\mathrm{RV}$ developed pressure

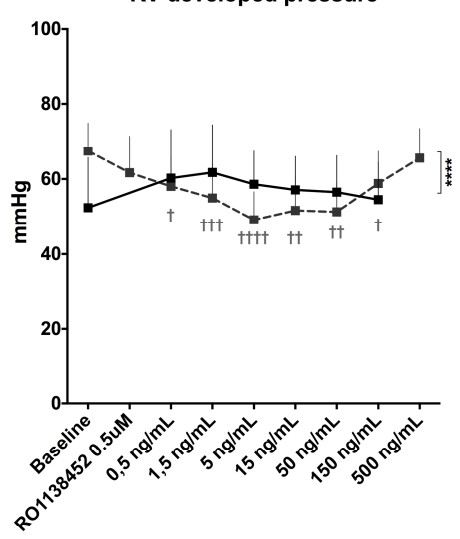

C Treprostinil + IP antagonist Heart rate

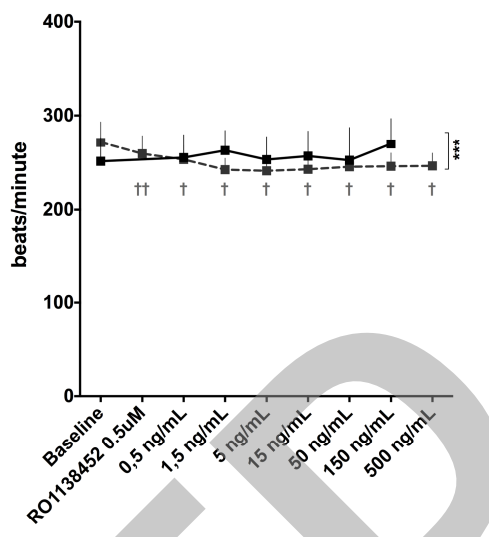

— Treprostinil _- Treprostinil + IPr antagonist 

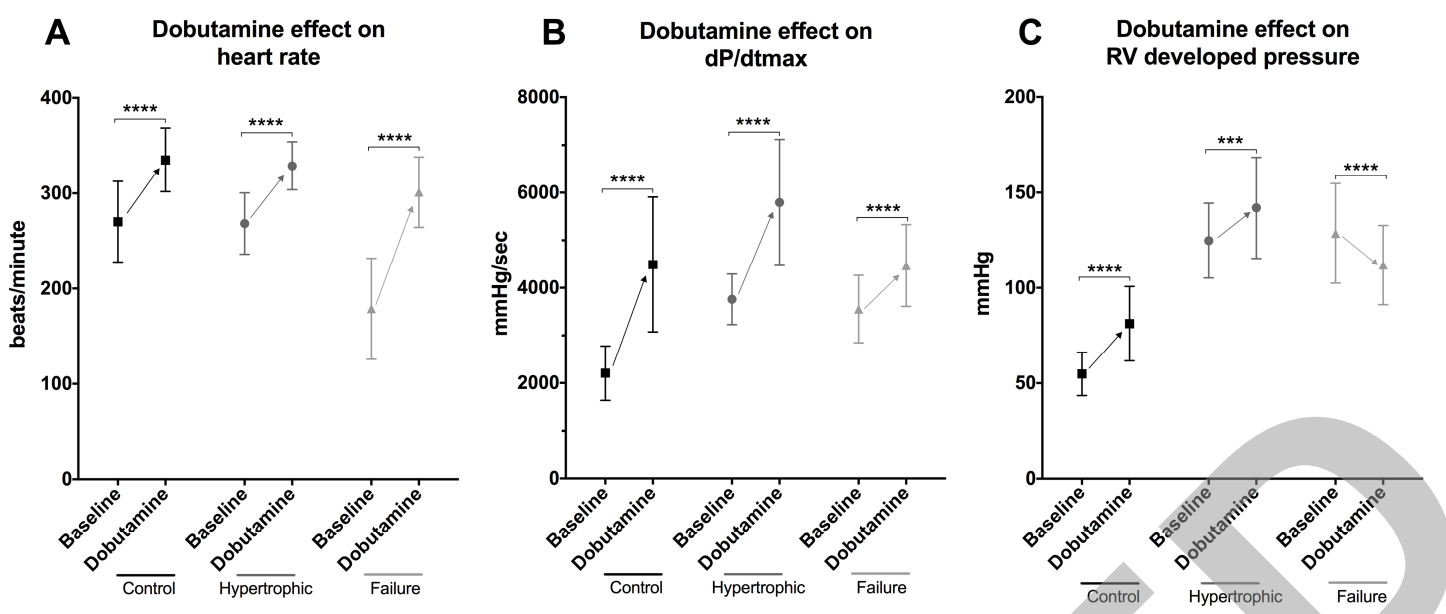

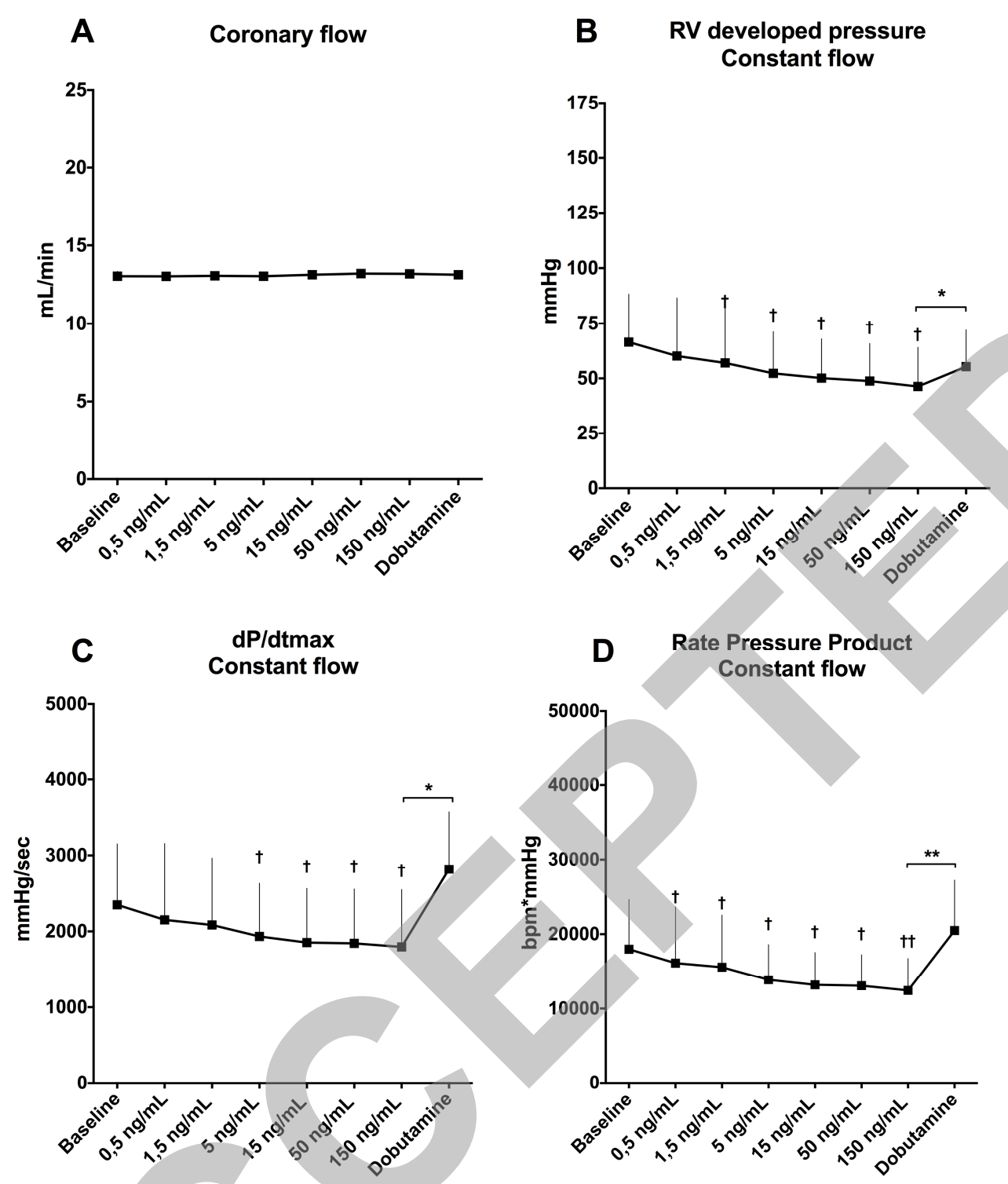

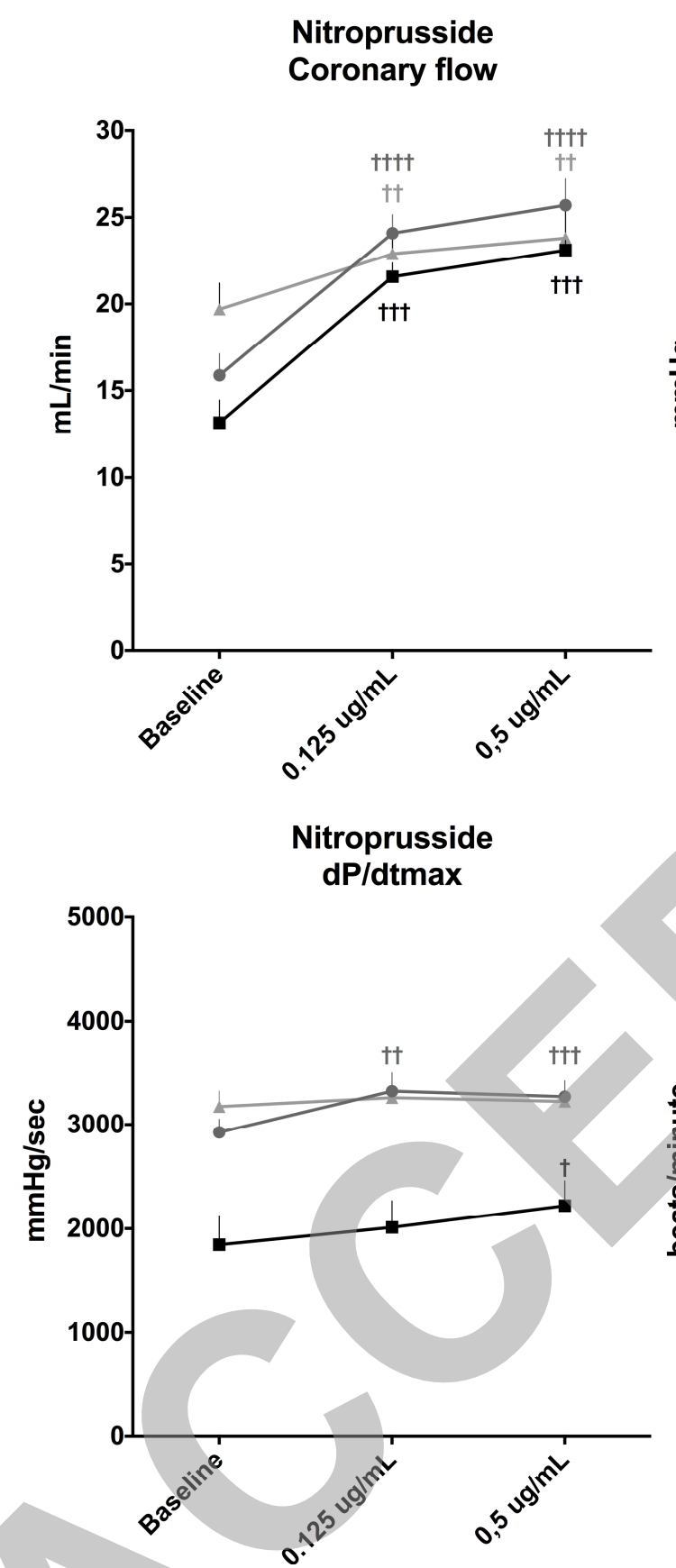

+ Control

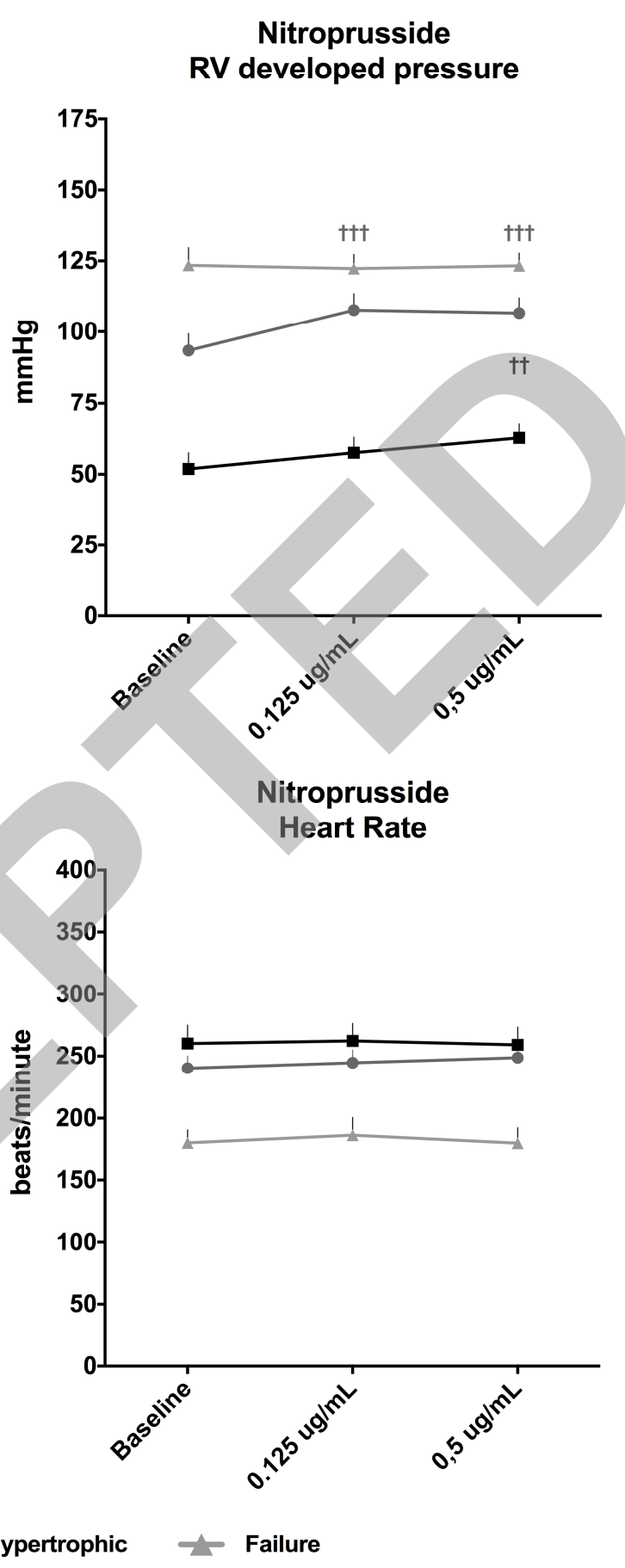




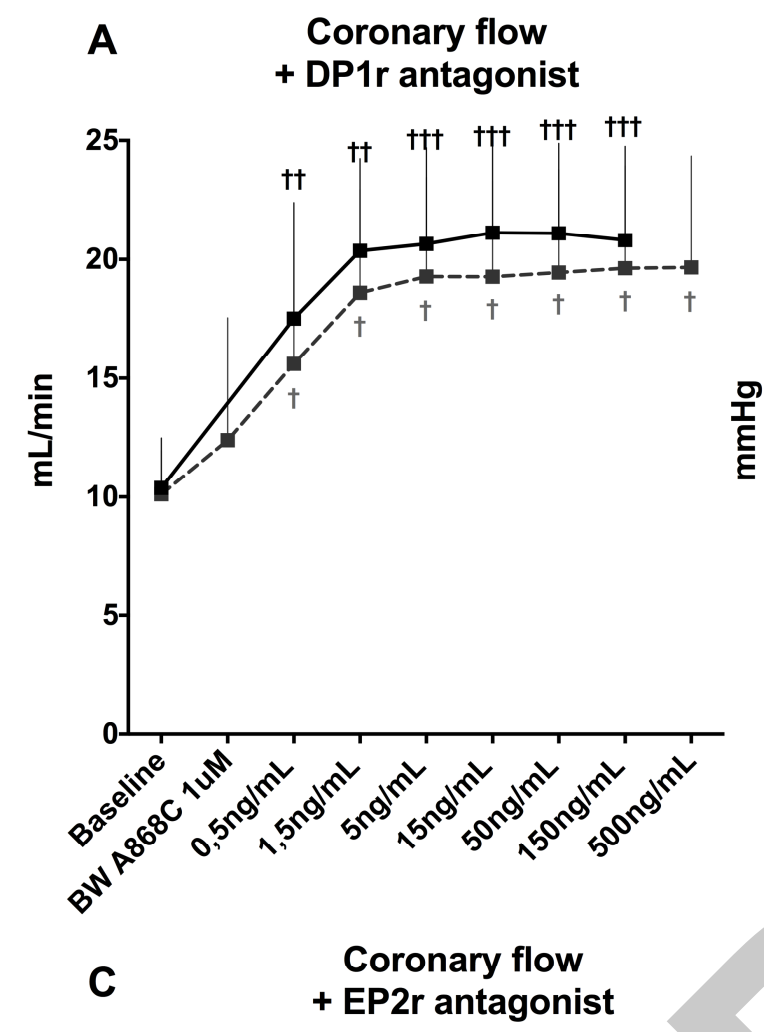
B RV Developed Pressure
+ DP1r antagonist

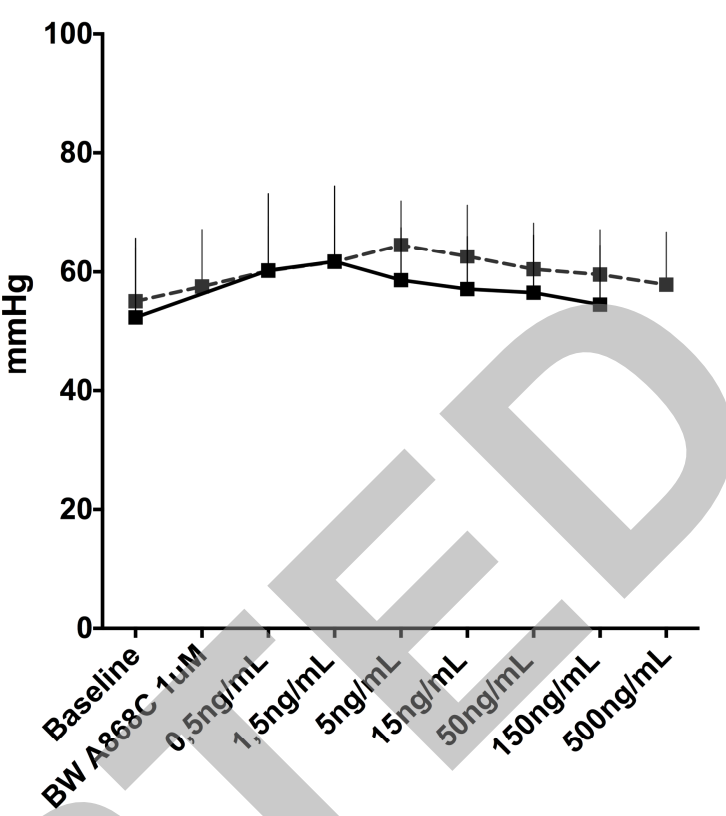

\section{RV developed pressure + EP2r antagonist}

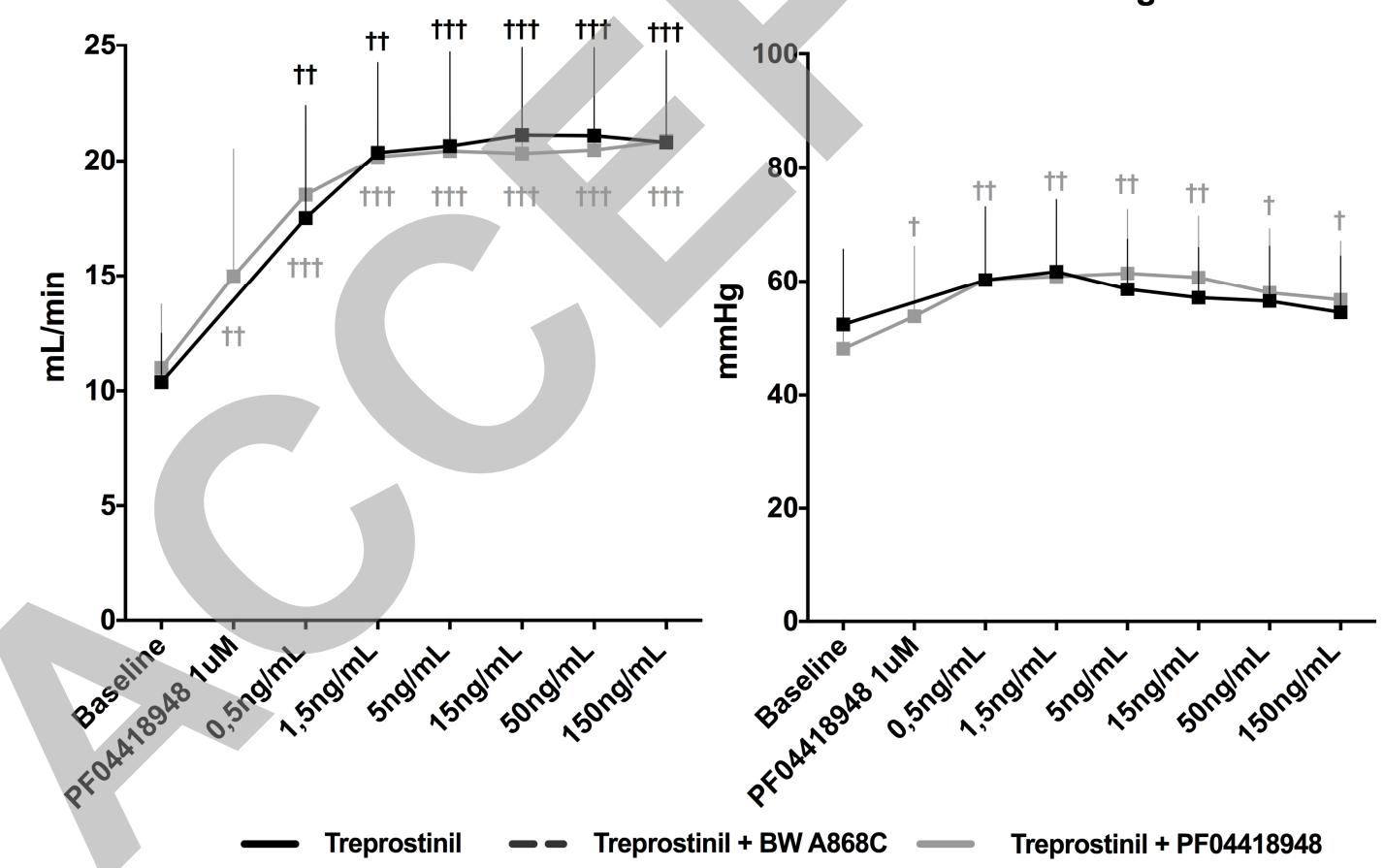

